\title{
DOMESTIC STAGFLATION AND MONETARY POLICY: THE FEDERAL RESERVE AND THE HIDDEN ELECTION
}

\section{Gerald Epstein}

As Jerry Ford left the White House he handed Jimmy Carter three envelopes, instructing him to open them one at a time as problems became overwhelming. After a year, Carter opened the first envelope. It said, "attack Jerry Ford." He did. A year later, Carter opened the second envelope. It said, "attack the Federal Reserve." He did. Three years into his term, and even more overwhelmed by the economy, Iran, Afghanistan and so forth, Carter opened the third envelope. It said: "prepare three envelopes."

Paul Volcker, January 1981

Ever since Richard Nixon's preelection machinations in 1972, it has been widely believed that presidents manipulate the economy to get reelected. Social scientists have developed an entire theory of "electoral business cycles" to describe this manipulation. ${ }^{1}$ The theory usually assumes that voters are myopic - they care about the direction in which the economy is moving the year before the election and tend to forgive sins committed two or three years earlier. It suggests that a president who wants to be reelected ought to create high unemployment levels in the first two years of his term to give himself room to reduce unemployment as the next election nears. This conforms with the common empirical finding that in assessing presidential performance in economic affairs, what voters care most about is how fast their income is growing the year before the election. The faster it grows, the more popular the president is likely to be.

Whatever the validity of electoral business cycle theory, Jimmy Carter, the consummate office seeker, did not follow its prescriptions. ${ }^{2}$ In fact, he seems to have reversed them. From 1977 to the middle of 1979, the economy experienced one of the longest peacetime expansions in its history. Real GNP grew at an annual average rate of 4 percent, and unemployment fell from 7.7 to 5.8 percent. But then the decline set in. In 1980, the growth rate of real income dropped to zero, workers' real weekly earnings fell by almost 3 percent, and unemployment skyrocketed back to 7.5 percent. Inflation, whose containment had been a major announced ad-

Jonathan Jacobson provided excellent research assistance. I would like to thank William Sweet, Carl Van Duyne, and Michael Wattleworth for providing useful material, and Raghbendra Jha and John Sheahan for helpful comments on an earlier draft. I would especially like to thank Thomas Ferguson, Joel Rogers, and Mark Breibart for extensive discussions on the material presented here. 


\section{THE H ID D E N E L E C T IO N}

ministration objective, was still almost double digit on election day. Not since Herbert Hoover had a president presided over an election-year economy that behaved so diametrically opposite to what social science and common sense would suggest to be the outcome of a reasonable reelection strategy.

What happened?

Popular commentary explains Carter's failure to manipulate the 1980 economy as a simple function of the doubling of OPEC oil prices in 1979. Since a large percentage of aggregate consumption goes to direct and indirect purchase of energy, spectacular price rises for that commodity have an almost immediate inflationary impact throughout the national economy. Rising energy costs have the additional effect of draining consumption from other sectors of the economy, thus reducing the demand for goods. As a consequence, production slows and unemployment rises. Such an explanation of simultaneous inflation and unemployment is misleading, however. Even before the I979 OPEC action, a series of domestic and international problems was developing that would critically affect the election. Single-minded attention to rising energy costs captures only part of the story.

The common explanation focuses on the president as the most important actor shaping the national economy. In the case of Jimmy Carter, such a focus is misplaced. Central to understanding the Carter administration's economic policy is a recognition of the degree to which the president deferred to the Federal Reserve in the shaping of that policy. Accepting presidential manipulation of the economy as a framework of analysis misses this outstanding feature of the Carter years. To the extent that anyone was in charge of the national economy, it was not the president, but the Federal Reserve. It is the Federal Reserve which has the formal power to manipulate interest rates and the money supply-crucial determinants of inflation, unemployment, and the value of the dollar. Moreover, it can do all this without presidential or congressional consent, and in this way is insulated from the pressures of electoral politics. Jimmy Carter appointed Paul Volcker to be chairman of the Federal Reserve; when the dust settled it was Volcker who remained to tell jokes on the Carter presidency.

But if the Fed can claim independence from electoral politics, its enormous authority makes it a crucible for other and equally important struggles for power. Exploring the institutional dynamics and constraints operating on the Federal Reserve not only shifts attention to the more relevant actor in the formation of national economic policy, but also brings into view all the larger conflicts now shaping the American political economy as a whole. It highlights as well a final irony of the Volcker joke. During the last two years of the Carter presidency not even the Federal Reserve could control the national economy. Wild vacillations in the economic climate triggered abrupt changes and policy reversals at the Fed. Unhappily for Jimmy Carter, no one was in charge. 
D O M EST I C S T A G F L A T ION

Consider the following chronology of major Reserve Board policy initiatives during the period:

On November 1, 1978, the Federal Reserve increased the discount rate by a full percentage point, the largest increase to date. The purpose, according to the Fed's chairman, G. William Miller, was to "call a halt" to the year-long decline in the foreign exchange value of the dollar. But after a short recovery, the dollar lost much of the ground it had gained.

Just a year before the election, Paul Volcker, the new chairman of the Fed, announced a major shift in its policy. Henceforth, he said, the Fed would control the growth in the money supply and let the market determine interest rates, regardless of how erratic they might become. Bringing the money supply under control, he said, would be necessary to fight inflation and speculation, and protect the dollar.

But on March 14, only six months later, the Federal Reserve was again forced to take dramatic action. The Fed announced a sweeping new battery of credit controls and restrictive policies to reduce the money supply. Over the next thirty days, the money supply did decline at an annual rate of over 14 percent, the largest monthly decline since the Great Depression. But from June to November it skyrocketed back up at an annual rate of over 15 percent. The prime rate jumped to almost 20 percent in April and plunged to 11 percent in July. The dollar followed right along.

In August, when Congress and the Reagan camp were in the midst of a frenzy of tax cut promises, Volcker made it clear that, in line with Carter's position, the Fed would not support such a cut. Citibank's Leif Olsen remarked, "Volcker's a strong man in the President's camp right now." But Volcker's marching orders came from elsewhere. On September 26 , less than six weeks before the election and over the strenuous complaints of the Carter administration, the Fed lifted its discount rate by a full percentage point, driving the prime rate upward again.

By election day, unemployment had risen to over 7.5 percent, the inflation rate was almost 10 percent, and workers' real wages had fallen almost 3 percent from the year before. Stagflation, the coincidence of low economic growth and high inflation, remained. At no time since the Great Depression has the Federal Reserve followed such a contractionary monetary policy in an election year, exercised its power over the financial sector to such a degree, and yet seemed in so little control of the economy.

How can one explain the confluence of such great political power and economic impotence in the context of the hidden election of 1980 ?

The Fed's power and problems result, in part, from an implicit "deal" within the political system. As problems mount and the necessary solutions become increasingly unpopular, Congress and the president attempt to escape blame by letting the independent Fed act. But this deal is only part of the explanation. The Fed also has its own views of what is necessary, and it uses its independence to impose them on the rest of us. At the same time, the Fed's independence is highly contingent. The Fed needs allies to protect it from the political process when its policies do not seem 


\section{THE HID DEN ELECTION}

so necessary to those in Congress, the White House, or the streets. For both historical and structural reasons, the financial community is such an ally. But allies rarely come for free.

Thus the Fed is being asked to solve increasingly intractable macroeconomic problems, wants to shape those solutions to fit its own view of the world, and needs to satisfy its political constituency-all at the same time.

These imperatives present a basic dilemma that neither simple monetarist solutions to tighten monetary policy nor dramatic supply-side policies to cut taxes can repeal. They therefore hold the key both to an understanding of macroeconomic policy in the hidden election, and the problems which won't go away when Reagan gets his turn.

\section{ST A G L A TION AND THE HIDDEN ELECTION}

Jimmy Carter's inability to find a solution to stagflation virtually eliminated his reelection chances, and Ronald Reagan faces the same prospect if he fails to fashion a cure. To understand Carter's failure and the imperatives facing Reagan, the roots of stagflation must be investigated. And although the causes of stagflation are not fully known, any analysis is doomed if it does not attempt to understand the implications of one central fact: the decline of United States power in the world economy since World War II. In the late 1940s, the United States produced 60 percent of the Western industrialized world's manufactures and 40 percent of the world's goods and services. By the late 1970s, both shares had been cut in half, and United States' manufacturing exports fared even worse. In 1953, almost 30 percent of Western industrial countries' manufactured exports were from the United States; by 1976, the United States share had shrunk to 13 percent. $^{3}$

Yet there is no simple connection between this decline and the economic and political crisis we now face. Though cries of American impotence were loudest in the 1970s, production and manufacturing export shares have stabilized or even increased in the last ten years. Ronald Reagan looks to Dwight Eisenhower for inspiration, but the largest proportion of the American decline occurred during his administration. Almost two-thirds of the reduction in United States' manufacturing production and export shares occurred in the 1950s, with almost half taking place between 1955 and 1960 .

The paradox of a partially stabilized international position in the face of massive domestic and international instability can be resolved if one understands, to put it crudely, that the chickens have come home to roost. The reduced position the United States finally reached by the late 1960 s rendered unstable institutional arrangements that depended so heavily on overriding American power and were so crucial to domestic prosperity and 
DOMESTICSTAG F LATION

political stability in the twenty years after World War II. ${ }^{4}$ The breakdown of the Bretton Woods system in 1971 and the OPEC price increase of 1974 were the critical events that consummated that fall. For the United States and the world economy to restore stability and growth, international and domestic restructuring of these arrangements is required. Yet persistent attempts by the United States to maintain its outmoded international role and the inability of anyone else to set up a new order not only help to explain the recently stabilized American international position, but have also precluded the restructuring that is actually required.

As a result of the failure to reconstruct an international order, domestic restructuring has become both much more important and much more difficult. The domestic implications of international stability are certainly complex, but to put it simply, the changed nature of the world economy, the American role in it, and the domestic pressures that result have boxed the United States into a corner. Both inflation and stagnation create problems. But inflation has become the only way to fight stagnation; and stagnation has become the only way to fight inflation. The combination-stagflation-represents an unhappy compromise of powerful forces and interests. It is a compromise that probably cannot last long, as the machinations of the recent election and the instability of the political coalitions associated with it suggest.

The inflationary consequences of fighting stagnation, and the stagnating consequences of fighting inflation, result from problems endemic to the way capitalist economies have always worked. The recent increase in the political power of labor at home and abroad, the current structure of the international monetary system, and the formation of the OPEC cartel have exacerbated the problems virtually to the point of crisis.

Throughout the history of capitalism, sustained economic expansion has created problems. The major one is that expansion eventually leads to tight labor markets as pools of unemployed labor dry up. Tight labor markets, in turn, reduce the threat of dismissal, almost inevitably leading to increased wage demands. More strikes and greater militance on the shop floor often also result, and both lead to lower productivity. Since manufacturers' profits depend on getting high output while paying low wages, all three factors squeeze profits as full employment is maintained. If firms can raise prices, they solve one problem but create another. By raising prices, manufacturing firms can protect their profits. If they do, however, the inflation that results from full employment affects others adversely, especially financial interests. Sustained full employment presents a dilemma, then. If prices do not increase, manufacturing profits are squeezed. ${ }^{5}$ If prices do increase, wealthy bondholders and the financial communityKeynes's rentier interests-are harmed. Inflation becomes the way to fight stagnation, but it is a way that places strains on financial markets and political conditions.

As economic expansion is maintained and manufacturers respond by raising prices and inflation, the powerful groups that are hurt, and the 


\section{THE HID DEN ELECTION}

financial markets, which function poorly with high and variable rates of inflation, begin to require recession and unemployment to restore decorum to the labor market and to create slack in other markets to reduce inflationary pressures. A recession can be created if Congress can be induced to raise taxes or to reduce government spending. But if groups in society and the bureaucracy are able to protect themselves from budget cuts and tax increases, then contractionary fiscal policy is not a real option.

A recession can also be created if the Federal Reserve tightens up on the money supply and raises interest rates. ${ }^{6}$ This reduces the availability of money and increases the cost of credit, reducing borrowing, sales, and economic growth. But tight monetary policy is particularly onerous for manufacturing interests. Tight money means higher interest rates and therefore higher costs for firms that borrow.

But whether monetary or fiscal policy is used, decorum in the labor markets is restored at a cost. High unemployment lowers sales and reduces profits. The longer it takes for unemployment to reduce wage demands, the costlier a recession is to manufacturing interests. In addition to raising prices and calling for contractionary macroeconomic policy, manufacturers have a third alternative. They can invest in new technologies that reduce their reliance on labor. But if the Federal Reserve is maintaining high interest rates to stem inflation, then this avenue of relief from the profit squeeze is undermined as well.

Indeed, the longer the recession and the tighter the monetary policy necessary to bring it about, the less likely a restoration of the conditions for profitability and long-term growth. Private investment, on which productivity growth and the accumulation of profits ultimately depend, is hindered by the high interest rates and excess capacity that induced recessions create. To make things worse, partly because of the increased power of labor, monetary policy and contractionary fiscal policy seem to be less and less effective in reducing wage increases and inflation. Tight money thus seems to lead to stagflation-it generates excess capacity and unemployment and lowers investment and productivity growth without putting much of a dent in inflation. ${ }^{7}$ The ability of the government to satisfy demands for lower inflation without imposing heavy costs on manufacturing interests is now greatly undermined by the fact that cutting government spending or increasing taxes are politically difficult courses. So financial institutions and markets turn to the Federal Reserve for relief. But the ability to control the course of the economy has been further undermined by the resistance of workers to cuts in wages even in the face of high unemployment. Stagnation thus comes to be the only way to fight inflation.

The configuration of the world economy in the wake of reduced American power and the unstable structures resulting from the failure to reconstruct a new order greatly exacerbate the inflationary consequences of expansion as well as the costs of stagnation. These problems in turn result from and exacerbate political conflicts of the highest order. 
D O MEST I C T A G F L A T I N

The machinations involve a host of characters: nation-states, classes within nations, and groups within classes. Ultimately these characters must be understood within the structure of the institutions they created, struggled over, and progressively undermined in the course of the postwar era. No international institution gives a better vantage point from which to understand this evolution and the problems created by its breakdown than the Bretton Woods system created by the allies at the end of World War II and officially dismantled by Richard Nixon in 1971. On the domestic front, few institutions have been a more important terrain for the struggle over Bretton Woods than the Federal Reserve. The contest over the Bretton Woods system, together with the reduced ability of the United States to control the world price of oil, put the problems of expansion and stagnation into their proper context, and lay the basis for understanding the macroeconomic dilemmas of the hidden election and beyond.

Bretton Woods created a system of fixed exchange rates based on the use of the dollar as the principal international currency. The United States pledged to buy dollars with gold at a fixed price. After the war, the United States produced goods and services Europeans and the Japanese needed to rebuild their shattered economies. As a result of both factors, foreign central banks were willing to accumulate and hold dollars in their foreign exchange reserves. The dollar became the major reserve currency of the international system. It was an arrangement that conferred considerable benefits on some actors within the international system, but not without considerable costs to others.

The primary benefit of the reserve currency role was that the United States could run chronic balance of payments deficits. In principle, it could have run a deficit by importing more goods and services than it exported (a trade deficit), or it could have invested more dollars abroad than foreigners invested in the United States (a capital account deficit). From the end of World War II until 1970, the United States exported more goods and services than it imported. But between 1950 and 1971, when Bretton Woods broke down, net United States financial outflows exceeded net exports (exports minus imports) in every year but three. ${ }^{8}$ The United States was able to run these deficits without the value of the dollar declining because foreign governments were willing to buy up the excess dollars flowing abroad, preventing the excess supply from driving down the dollar's value.

The French referred to this ability of the United States to run chronic balance of payments deficits-buying up factories by simply printing money-as the "exorbitant privilege." The standard view of the American acquisition of that privilege is expressed well by James Tobin, a member of the Council of Economic Advisers under President Kennedy: "The United States did not seek this privileged role; it arose by accidental evolution rather than by conscious design. ${ }^{\prime \prime} \mathrm{C}$. Fred Bergsten, assistant secretary of the Treasury for international affairs under Carter, takes a strikingly different view: 


\section{THE HID DEN ELECTION}

In effect, the United States used the IMF as a multilateral cover for its national dominance-which of course also had the merit for other countries of providing a cover for their impotence, and some actual protection against the United States. It decided to handle the issues unilaterally, and usually did so quite generously and quite well. However, in the process it created a system based on the dollar and U.S. hegemony rather than on the IMF and international cooperation. . . . Achievement of key currency status does require a choice by the dominant country, at least to the extent of rejecting the possible alternatives, and it is a mistake to say-as many commentators and officials do, for understandable if erroneous political reasons-that the United States did not seek the reserve currency role, but had it thrust upon us. ${ }^{10}$

The benefits from the exorbitant privilege were not distributed equally over time or across groups. The institution of fixed exchange rates helped to create international stability, which was conducive to international trade, economic growth, and the fight against communism in Europe and Japan. In the process, United States' direct investment grew at a steady rate of 10 percent per year from 1950 to 1960 . The rate of growth of this investment was higher in Europe than elsewhere: there it grew at 13 percent per year, a pace which was especially upsetting to the French. ${ }^{11}$

The ability of the United States to run chronic deficits because of the key role of the dollar facilitated the ability of the multinational corporations to expand around the world buying land and factories and hiring cheap labor without the government having to impose excessive austerity on the domestic population in order to reduce imports. That, in turn, helped to maintain the domestic political conditions for multinational expansion. But these conditions could not be maintained forever. In the 1950s, Yale economist Robert Triffin was already pointing out a fundamental weakness in the Bretton Woods system: the rest of the world needed dollars to carry out international finance and trade, but the only way in which the dollars could be provided was by the United States running balance of payments deficits. Those deficits, however, would eventually undermine the world's confidence that the dollars would be redeemable for gold or goods at reasonable prices. As its foreign investments multiplied and the United States began importing more from abroad and producing a smaller proportion of the world's output, the value of dollars held by central banks came perilously close to the value of the United States' gold stock. One dramatic danger was that foreigners would demand gold for their dollars, as provided in the Bretton Woods agreements. Indeed, between 1957 and 1960 over a quarter of the American gold stock was bought by foreign central banks, mainly the French. ${ }^{12}$

By 1959, the United States had lost over 60 percent of the share of manufacturing exports it had won along with World War II. With less demand for dollars with which to buy goods, and with private and official confidence in the ability of the United States to maintain the value of the 
D O MESTIC S T A G LATION

dollar waning, substitutes for intrinsic value had to be found to convince others to hold onto dollar reserves. For the next ten years, the major financial question facing American policymakers, including the Federal Reserve, was how to maintain the Bretton Woods system despite the declining relative power of the United States.

Arthur Schlesinger reports that, upon entering the White House, the two things that worried John Kennedy the most were nuclear war and the balance of payments. ${ }^{13}$ (He does not say in which order.) As Kennedy took office in 1961 , the unemployment rate was almost 8 percent. The Council of Economic Advisers was committed to reviving the growth of the domestic economy and was willing to reduce the role of the dollar in international affairs, if that was what it would take. To revive economic growth, the council preferred a policy mix of low interest rates to stimulate investment and government budgets balanced at full employment. But as James Tobin, a member of Kennedy's council, put it: "A really aggressive monetary expansion was not in the cards because of the balance of payments." ${ }^{14} \mathrm{~A}$ loose monetary policy would have lowered interest rates. With interest rates lower at home than abroad, investors would have sold dollars to buy foreign currencies. The outflow of dollars, in turn, would have worsened the balance of payments, placing another nail in the coffin of Bretton Woods. As the chairman of the Fed, William M. Martin, explained: "Even if indeed an occasion arose when we could preserve the international role of the dollar only at the expense of modifying our favored domestic policies-even then we would need to pay attention to the international repercussions of our actions."15 But eventually, the Bretton Woods system and the high interest rates used to protect it became especially onerous for domestic manufacturers.

In principle, a number of policies could have been undertaken that would have reduced the need for tight money to protect the balance of payments and Bretton Woods. One solution was to devalue the dollar. That would have increased the cost of imports and reduced the cost of American goods to foreigners, thus helping to restore the competitive position of the United States at home and abroad. Dollar devaluation faced a host of obstacles, however.

For one, Europe and Japan were enjoying the high dollar exchange rate that made their goods cheaper in American markets and American goods more expensive in their own. In 1950, for example, the dollar cost of Japanese goods was half as high as that of American goods, and German, French, Italian, and British goods were three-quarters as expensive. ${ }^{16} \mathrm{By}$ the mid-sixties their cost advantage had eroded, and they would have been reluctant to let a dollar devaluation erode that advantage any further. On the American side there was strong opposition to devaluation, particularly from financial interests. They believed devaluation would lead to inflation. If the dollar falls in value, that increases the cost of imports and allows domestic producers to raise their prices in tandem. The reasons financial interests tend to oppose inflation are worth looking at with 


\section{THE H I D D E N E L E C T ION}

some care, since some interesting divisions among them will arise.

The standard textbook maxim holds that debtors gain from inflation while creditors are hurt. This follows since debtors are able to repay creditors in dollars worth less than those they borrowed. If, however, inflation is expected, or even if it is not expected but can be quickly adjusted to, lenders are likely to extract higher interest rates to compensate for the reduced value of the dollars repaid. The shorter term the loan, the more flexible the credit arrangement, and the more power they have to alter contracts, the less creditors are harmed by inflation. As part and parcel of the conventional wisdom, it is commonly believed that, being creditors, banks dislike inflation. And, in fact, investment banks, which engage in long-term credit activities, have a good deal to fear from high and variable inflation-which, it appears, have gone hand in hand. When interest rates increase because of expectations of increased inflation, bond prices fall since the returns the owners of the bonds receive are lower than they could get on the open market. The drop in bond prices lowers the value of the bonds. Bondholders, quite naturally, become reluctant to take similar risks in the future. In general, when inflation is high and variable, interest rates and bond prices fluctuate as well.

As a result, buying, selling, and underwriting long-term debt becomes a risky and less profitable business. Small commercial banks and savings and loans, because of government regulations, narrow market position, and few resources to devote to innovation, have relatively little flexibility in changing interest rates as inflation and market interest rates vary. They also tend to be harmed by high and variable inflation. Large multinational commercial banks, on the other hand, operate in a broad range of domestic and international markets and have great financial resources for innovation. They are therefore able to adjust quite quickly to an inflationary environment. They have, however, more subtle and complex problems with a large devaluation, which I describe below.

Finally, many feared that devaluation would actually destroy the Bretton Woods system. Since many countries held much of their reserves in dollars, devaluation could have cost them dearly. It would have disrupted economic and political relations among the major industrial powers, and harmed American interests as well. One way out of the impasse was to find a way to reduce the reliance of the international monetary system on the dollar. That would allow the United States to pursue a looser monetary policy without worrying that an excessive dollar outflow would undermine the very basis of the system; in the extreme, it might allow devaluation without disrupting the entire system. Proposals to reduce the reliance of the international monetary system on the dollar had been suggested periodically, especially during times of dollar weakness. Two recurring ones were the creation of a world money that could at least partly satisfy the need of central banks for reserves, thereby reducing their reliance on the dollar; and a substitution account, which would create an asset dollar holders could substitute for their dollars without having to sell them on 


\title{
D O M E T IC S T A G F L A T O N
}

the foreign exchange market. That would avoid exchange market instability and could help preserve Bretton Woods without requiring United States' monetary policy to be as restrictive as it would have to be otherwise.

Proposals to create an international currency under the auspices of the IMF were introduced throughout the 1960s. The first substitution account plan was proposed at the IMF annual meeting in Washington in September 1962. The so-called Maudling plan would have allowed central banks to deposit unwanted currencies in a mutual currency account, in exchange for international money whose value would be guaranteed in gold. Thus, any participating country worried about the future value of the dollars it was holding could get a gold-based guarantee of that currency's value without having to sell the dollars for gold. The initiative received no support from the official community gathered in Washington. Robert Roosa, an investment banker and undersecretary of the Treasury under Kennedy, would have no part of it. ${ }^{17}$ Roosa's opposition was no aberration. Throughout the early sixties, American financial institutions and the Treasury Department fought tooth and nail all proposals that would reduce the reserve currency role of the dollar, including those that called for the creation of an international currency and for a substitution account. Those who proposed a reduction in that role had a well-defined view of the basis for this opposition. James Tobin, a scarred veteran of these battles within the Kennedy administration, described the view in the following terms:

\begin{abstract}
The reluctance of U.S. financial circles to accept a solution that recognizes the decline in the reserve-currency status of the dollar seems to be based on a misunderstanding. It is feared that such a solution will also displace the dollar from its role as the principal medium of exchange in private international transactions. This would lose New York and the country some financial business and income, and the nation would no longer enjoy the ability to finance payments deficits from the yearly increment of private foreign demand for dollar working balances. . . . But no one is proposing to create an international money for private circulation. There the dollar will remain unchallenged. ... Indeed, any international monetary reform that removes the danger of a run from dollars into gold can only strengthen the world's private demand for dollars. ${ }^{18}$
\end{abstract}

But Roosa was not convinced. In a famous debate on this point, Roosa admitted that reducing the reserve currency role of the dollar without harming American financial institutions might be possible, but he quickly added: "Separating the transactions (private) roles from the Reserve currency role would be as delicate as separating Siamese Twins."19

Moreover, the major multinational banks knew that their fate was tied up with world economic growth and international trade in general, and the fate of American multinational corporations in particular. Banks make money by financing the production and trade of their customers. Small 


\section{THE HID DEN ELECTION}

American banks were more or less confined to financing domestic production in the 1950 os and 1960s, so their primary concern was with domestic growth and trade (as long as growth was not inflationary). But large international banks had a global reach: their concern was that the open trading system of Bretton Woods, which contributed to world economic growth, be maintained. They had a special interest in the growth, profitability, and expansion abroad of American multinational corporations, for here they had an edge on their domestic and foreign financial competition. The major advantage that large American commercial and to some extent investment banks had over domestic and foreign competitors under the Bretton Woods system was their familiarity and close relationships with American multinational corporations that moved abroad. Laws that prohibit interstate branching in the United States in order to protect small domestic banks have until recently been notoriously difficult for large banks to break. There were few laws against American banks setting up branches overseas, however, especially in the unregulated offshore markets. Eastern banks were better able to serve their large corporate customers if they moved from the East Coast to London than if they moved from New York to Texas. Large established banks knew that their futures lay with the growth of the multinationals. This growth in turn depended on the companies' having access to profitable opportunities abroad, and the resources to pay for them. One way to get such resources, of course, was by maintaining the reserve currency role of the dollar.

But by the late 1960s, the costs in tight money and high interest to maintain the system, and the system itself, greatly reduced or even eliminated the "exorbitant privilege" accruing to broad sectors of the American business community. The major problem was that the longer Bretton Woods was maintained, the longer the fixed dollar exchange rate was overvalued. That meant that imports remained cheap and exports remained relatively expensive, harming domestic manufacturing interests. In 1950, Japanese products were half as expensive as American products; in 1970 they were still one-third cheaper. In 1950, German goods cost 72 percent of American goods; in 1970, they still cost only four-fifths as much. ${ }^{20}$ It is common to blame cheap foreign labor for the fact that the competitiveness of American manufacturing was eroded at home and abroad. But the high interest rates used to protect the balance of payments, which inhibited borrowing, investment, and expansion by domestic manufacturers, and the overvalued exchange rates were the real culprits. The desire to preserve the reserve currency role of the dollar and to avoid the inflationary impact of devaluation had led the Fed and the Treasury to fight proposals for dollar devaluation and the reduced role of the dollar that might entail.

In 1966, President Johnson stepped up the Vietnam war spending while refusing to risk popular disaffection by increasing taxes to pay for it. The increased spending, then as now, led to a major dilemma for the Fed. Monetary policy in 1966 almost caused a collapse of the housing 


\section{DOMESTIC STAGFLATION}

market in California and the savings and loan associations connected with it. The tax surcharge in 1968 was not sufficient to fight inflation and restore decorum in the labor market, which had to contend with 4 percent unemployment or less for two years in a row. Martin maintained tight monetary policy in 1969 and early 1970 , and $\$ 4$ billion flowed into the United States from abroad, but the credit crunch almost created a financial panic. ${ }^{21}$

When Arthur Burns was appointed chairman of the Federal Reserve by Nixon in 1970, he reversed the tight money course. In August 1971, President Nixon officially dismantled the Bretton Woods system by refusing to convert dollars into gold and by devaluing the dollar. It is commonly believed that Nixon abandoned Bretton Woods because he was forced to do so by international creditors, who were demanding more gold than the U.S. government had. However inevitable Bretton Woods' collapse, the American government had some control over its timing. Nixon abandoned Bretton Woods when he did in order to devalue the dollar, restore American manufacturing's international competitiveness, and avoid the stagnating effects of tight monetary policy on the domestic economy. ${ }^{22}$ Nixon had appointed Arthur Burns to the Fed to help facilitate this process. But the long-term attempt by the Fed and the Treasury to maintain the outmoded role of the dollar and its international position might well have already done its damage. As C. Fred Bergsten, Carter's assistant secretary of the Treasury, put it before he took office:

Since it was such financial concerns which permitted the dollar to become overvalued by 1971 and cause significant losses of jobs for Americans, perhaps the Treasury Department and the Federal Reserve Board, rather than U.S. trade negotiators, should be accused of "selling out U.S. interests to the foreigners. ${ }^{\prime 23}$

The roots of the decline of the U.S. domestic manufacturing sector and productivity growth might well be sought, then, in the effects of the Bretton Woods system and the policies undertaken to maintain it.

Federal Reserve concern with the welfare of banks in general and their international expansion in particular was not new in the 1960s. From its inception, the Federal Reserve has had a very close-one might say intimate-relationship with the financial community in the United States. The standard textbook explanation of the founding fathers' rationale for creating the Fed is straightforward:

The Federal Reserve System was created by Congress in 1913 to avoid the banking crises that had periodically plagued the United States economy -the most recent of which was the panic of $1907 .{ }^{24}$

But the explanation, while partially true, is highly misleading. The Fed was created not only to alleviate banking panics, but also to keep the money supply out of democratic control, to facilitate the cartelization of the bank- 


\section{THE H ID DEN ELECTION}

ing system by the largest banks, and last, but far from least, to help large American financial firms compete better with European ones. Although these goals were not perfectly embodied at the inception of the systemnor are they fully realized today-they have been the system's driving force throughout its history.

Following the panic of 1907 , large banks developed various proposals for a central bank. But large and small banks were bitterly divided over proposals for reform. Generally, smaller banks were apathetic or deeply opposed to any central system, fearing that it would be controlled from New York. For their part, large banks, and especially those in New York, wanted a centralized system, one they could control, one that would stop their relative decline in power domestically, and one that would provide policies which would enhance their ability to compete in international financial markets. These proposals emerged at a time of great social agitation in the United States. The Socialist party, liberal reformers, and Bryan Democrats, among others, were pushing for broad social changes, not the least of which was the dismantling of the large Eastern "Money Trusts" and for more public control over the money supply.

The fear of more radical reforms and the particular interests of large bankers led to a compromise between the large and small banks by which the new monetary authority would be decentralized. There would be regional reserve banks subject to the control of a central Board of Governors located in Washington and appointed by the president, rather than one central bank controlled by bankers. The Federal Reserve Act signed by Wilson toward the end of 1913 provided for as many as twelve regional banks, leaving the Board of Governors in Washington, however, with little formal power. In a common assessment, Galbraith concludes that "The regional idea had, in fact, triumphed and the real authority lay with the twelve banks." 25 This view is misleading, however. The real power in the early days of the system lay with the New York Federal Reserve bank and the large Eastern interests it represented. Under the powerful leadership of Benjamin Strong, the New York Fed won most of the internal battles bitterly contested by Washington.

Despite the compromises, Benjamin Strong and other important early figures in the Federal Reserve understood the importance of the new bank. As Strong put it in 1915: ". . if all such prejudices, political and sectional, against New York and its bankers can be overcome by such measures as have been adopted in the Federal Reserve Act, I should feel that the work now being done has been well repaid." 26 And while political protection of bankers was a goal well served by the establishment of the Federal Reserve, promoting New York's international role was an equally important objective. As Carter Glass, who was instrumental in the creation of the system, told a Washington audience:

The proponents of the Federal Reserve Act had no idea of impairing the rightful prestige of New York as the financial metropolis of this hemi- 
DOMESTIC STAG FLATION

sphere. They rather expected to confirm its distinction, and even hoped to assist powerfully in wresting the scepter from London, and eventually making New York the financial center of the world. Eminent Englishmen with the keenest perception have frankly expressed apprehension of such a result. Indeed, momentarily this has come to pass. And we may point to the amazing contrast between New York under the old system in 1907, shaken to its very foundations because of two bank failures, and New York at the present time, under the new system, serenely secure in its domestic banking operations and confidently financing the great enterprises of European nations at war. ${ }^{27}$

But the big bankers in New York and elsewhere did not get everything they wanted from the Federal Reserve. To gain support for the system, membership was made voluntary, and the government maintained control over the appointments to the board in Washington. The division of authority between New York and Washington, the ability of state banks to stay out of the system, and the ultimate power that Congress, in principle, could exercise meant that big bank control over monetary policy and big bank control over the banking system were not guaranteed.

After the debacles of the 1930s, power within the Federal Reserve System was largely transferred from the regional reserve banks to the Board of Governors in Washington through a series of legislative and administrative reforms. This shift is commonly seen as representing the virtual elimination of banker control over the policies of the Federal Reserve and the consolidation of a central bank under public control. The real story is more complex. Recent evidence indicates that the movement actually represented the triumph of Midwestern and California banks over the New York financial interests for representation within the policymaking structure of the Federal Reserve. The shift broadened the interests represented in the Fed and reduced the debilitating battle for power between New York and Washington by centralizing control in Washington. ${ }^{28}$

Such centralized control and broadened interests also meant that longer-range views of what was necessary to protect the financial integrity and profitability of American financial institutions on a domestic and international scale were more likely to inform Federal Reserve policies. But the contingent nature of the Federal Reserve's independence from Congress and the executive, and the important political power of small banks in Congress, meant that the Fed would not always be able to follow the policies necessary to maintain the longer-run interests of the financial community. The Federal Reserve needed the support of the financial community to preserve its independence from the government. But that support has a price, which often has to be paid in terms of the narrow interests of its supporters.

Milton Friedman is one of the few economists who understands this problem, on one level at least. He believes that the best way to fight inflation and maintain the conditions for stable economic growth is for the 


\title{
THE HID DEN ELECTION
}

Federal Reserve to control the money supply. But for most of its life the Fed has chosen to try to control interest rates (credit conditions) instead. Friedman attributes this decision to a simple fact:

\begin{abstract}
An independent central bank will almost inevitably give undue emphasis to the point of view of bankers. ... In the United States, for example, the Reserve banks technically are owned by their member banks. One result is that the general views of the banking community exercise a strong influence on the central bank, and since the banking community is concerned primarily with the credit market (interest rates), central banks are led to put altogether too much emphasis on the credit effects of their policies and too little emphasis on the monetary effects of their policies. ${ }^{29}$
\end{abstract}

Friedman goes on to say that in the United States, in principle, "the central bank can make the amount of money anything it wishes." But the dilemma of banker influence is deeper than Friedman recognizes. The Fed's dependence on bankers for its political independence means that the Fed is unable politically to impose the burdens of long-run monetary control on its political constituency, even if it chose to control the money supply. The problem is that whenever the Fed tries to control one form of money, financial institutions create another form that is not subject to the Fed's control. Financial institutions create new moneys like credit cards, because it is profitable for them to do so. In principle the Fed could prevent such innovation, but only at the expense of financial profits. And when it creates policies that harm those, it must pick its fights carefully and from a position of strength.

The ability of the Federal Reserve to control the money supply in the long run is also undermined by the international integration of financial markets. The Eurocurrency market is just one example of an international institutional innovation that creates a new kind of money, Eurodollars, which hinders the Federal Reserve's control of the money supply. This dilemma is very deep and goes to the heart of Milton Friedman's famous tenet that, to control inflation, the Federal Reserve should pick a particular money supply and cause it to grow at a constant rate. If the Fed cannot control the money supply, then the political process will have to find some other means to protect financial institutions and markets from the inflationary consequences of expansion.

The breakdown of Bretton Woods in 1971 and the advent of flexible exchange rates in 1973 altered the situation, as did the dramatic increase in oil prices and accumulation of OPEC wealth that soon followed. They both increased the need for and benefits from inflation and they both undermined the ability to stop it without generating stagnation.

As I suggested earlier, full employment leads to a profit squeeze for manufacturing corporations by increasing the militance of workers. Manufacturers can respond to the profit squeeze in a number of ways. One is by raising prices to protect profits. But for that to work for manufacturers 


\section{DOMESTIC S T A G F A TION}

in general, a number of conditions must hold. First, the Federal Reserve must increase the money supply. This results from a simple fact: if more money is not available to buy all the output produced at the higher cost, then some of the output will not be sold. ${ }^{30}$ Higher unemployment and lower sales and profits will result. Federal Reserve--created inflation might be one way to fight the profit squeeze brought on by sustained full employment, and indeed for this reason the Fed is routinely pressured to expand the money supply, thus maintaining inflation. But for inflation to maintain manufacturing profits in the face of lower productivity or higher wage demands, a second condition must be satisfied. Firms must be able to raise prices faster than workers raise their wages. There is in fact strong evidence that in the United States, increases in the rate of growth of the money supply do increase manufacturer profits, primarily because wages do not keep up with prices. ${ }^{31}$

One further condition is required for higher prices to solve the problems posed by sustained full employment: firms must be able to raise prices without being undercut by foreign competition. Under the Bretton Woods system of fixed exchange rates, however, this condition could not be met. If domestic manufacturers tried to raise prices, foreign competitors could undersell American manufacturers at home and abroad. ${ }^{32}$ The difficulties firms had in passing on higher wage costs partly explains why so many wanted a dollar devaluation and a shift to floating exchange rates, even if that meant the destruction of the Bretton Woods system. Floating exchange rates can protect domestic manufacturers from the detrimental profit effects of maintained expansion. As costs go up, firms can raise their prices. If such price rises are sufficiently widespread, the dollar will depreciate. The fall in the value of the dollar will increase the costs of imports, thus protecting domestic firms' markets in the United States while making American exports cheaper, protecting their markets abroad.

This competitive edge can be maintained, however, only if nominal wages do not go up with the dollar depreciation, even though the depreciation-induced inflation erodes workers' real wages. The Fed is thus faced with a dilemma. If it tightens monetary policy to reduce the inflation caused by a devaluation, profits and sales will be reduced. If it allows the devaluation-induced inflation to erode workers' real wages and restore the profitability of manufacturers, financial interests and markets will be harmed. If the workers attempt to maintain their real wages by increasing their wage demands, the dilemma becomes exacerbated. If workers' wages go up and manufacturers raise prices, that will cause the dollar to devalue even more. The economy may fall into a vicious circle of devaluation, inflation, devaluation that might be extremely difficult to break. ${ }^{33}$ As long as workers' wages lag sufficiently behind prices, however, manufacturers can benefit from devaluation and the inflation that results.

Thus the breakdown of Bretton Woods and the advent of floating exchange rates loosened the strait jacket on American economic growth that had become ever tighter during the late 1960s. But the breakdown 
THE HID DEN ELECTION

also meant that expansion might become more inflationary as it led to dollar depreciation. At the same time, although dollar depreciations were useful in restoring the international position of American exports in the world economy, they could do so only if workers' wage demands could be held in check and if the inflationary consequences were not too unsettling to American financial interests. ${ }^{34}$ In the longer run lurked a more dangerous possibility. In the face of the reduced share of American production in the world economy, attempts to maintain the role of the dollar might re-create the old Bretton Woods dilemma. American economic expansion might have to be called to a halt to prevent massive instability on the foreign exchange markets and the breakdown of the international financial system. It was such concerns that led ultimately to the Fed's halting of the 1976-1979 U.S. economic expansion. On the other hand, paradoxically, floating exchange rates, along with the pricing policy of OPEC, and major increases in the labor force help explain why the Fed allowed the expansion to go on as long as it did.

The fact that OPEC priced its oil in dollars and held much of its accumulated wealth in dollar assets created new opportunities as well as dangers for American financial and manufacturing interests. Oil price increases meant that other countries needed to use more dollars to buy OPEC oil, and OPEC would hold more dollars in assets. Both factors helped to maintain the international position of American financial institutions in the short run. Moreover, the pricing of oil in dollars gave other countries an incentive to let their currencies appreciate against the dollar, since that reduced the cost of oil to them in their own currencies. This in turn helped to restore the competitiveness of American manufacturing. By the middle of 1980 , the average unit labor costs in the United States were lower than those in Japan, Germany, France, and the United Kingdom; and in 1978, the cost of an average basket of goods in Japan, Germany, and France was 27,35 , and 14 percent higher than in the United States. ${ }^{35}$

But the OPEC cartel posed grave dangers as well. Increases in OPEC oil prices meant that the real standard of living in the United States had to fall if oil imports were to be maintained. Corporate profits, wages, or government spending would therefore have to fall in turn. Again, for manufacturers, inflation was the preferred solution. If they could raise their prices to compensate for the higher cost of oil and workers could not raise their wages commensurately, then workers' real wages would fall to pay for OPEC oil. All other things being equal, financial institutions would have opposed this solution. But two factors mitigated this opposition. First, after the initial OPEC price rise, OPEC acted somewhat like American workers. It failed to increase its oil prices to keep up with the cost of the goods the West sold it. By inflating, the United States was able to reduce the real cost of OPEC oil, and the amount of wealth the West transferred to the OPEC countries. Most sectors of American business wanted to minimize the wealth that escaped their control. Large accretions of wealth usually imply large accretions of power, which the business 
DOMESTICSTAGFLATION

community, the American government, and the Federal Reserve were anxious to prevent. As Anthony Solomon, president of the New York Federal Reserve, put it in a recent speech:

Our objective should be to take out of OPEC's hands the ability to force real oil prices higher, to unblock OPEC restraints on oil production, and to retain in our country the money that would otherwise be paid as tax to OPEC members in the form of higher oil prices. ${ }^{36}$

Second, in order to pay for OPEC oil, all interests desired an export surplus, which a controlled depreciation of the dollar could bring about. But a strategy of inflating away OPEC's wealth and controlled exchange depreciation could only work for so long. Decisions by the OPEC countries to hold fewer dollars in their reserves as their value fell-or, worse yet, to stop pricing oil in dollars-could cause downward pressure on the external value of the dollar. The simple existence of this possibility could, in times of general instability, cause massive speculation against the dollar and turmoil in international financial and commodity markets that was greatly worsened by expansion and attempts at controlled depreciation.

The difficulties the United States had in bringing about a controlled depreciation and creating an export surplus to pay for OPEC oil were greatly heightened by increased international competition with Europe and Japan in the wake of the American decline and as a result of the power of the European working class. In the United States, as I suggested, workers' wages do seem to lag behind prices. There is strong evidence that in Europe, however, wages do not lag behind by nearly as much, if at all. Why this differential relationship holds is not completely understood. But whatever its cause, it is of great importance. Expansionary policy in Europe is more likely to lead to exacerbated inflation as wages quickly catch up with prices, without a reduction in the wage share of income. In virtually all European countries, the share of wages in manufacturing income increased between 1964 and 1978. In Germany, it went from 63 to 71 percent; in France, from 52 to 54 percent; in Italy, from 64 to 72 percent; and in the United Kingdom, from 70 to 84 percent. ${ }^{37}$ There is good reason to believe that slow economic growth became a consensus policy in Europe in the 1970 s partly because of the increased labor share and the inability of expansion to reduce it. ${ }^{38}$ Indeed, there is some evidence that the strategy may have worked. During the second oil price increase in 1979, European workers' real wages were eroded much more quickly and to a much greater extent than they had been in the wake of the first price increase. ${ }^{39}$

Equally important, Europeans wanted to reduce the transfer of wealth from them to OPEC. They therefore wanted to reduce oil consumption by lowering economic growth. And, equally significant, they also wanted to generate an export surplus to pay for OPEC oil. The nature of the labor markets in Europe, the governments' response to them, and their desire for an export surplus all affected the ability of the United States to expand in 


\section{THE HID DEN ELECTION}

the mid-1970s without undermining the dollar and creating inflationary pressures.

From 1976 to 1978 , the failure of Europe to grow rapidly and increase its imports meant that the United States balance of payments deficit and downward pressure on the dollar were greatly exacerbated. Aware of the problem, Carter's economic advisers and the Fed's Miller kept cajoling Europe to grow faster. But the relative militancy of the working class in Europe and export imperatives constrained the ability of American capitalism to satisfy its manufacturers' demands for growth without undermining American and international financial institutions and markets. Thus, when their costs finally outweighed their benefits, financial institutions finally demanded an end to growth, inflation, depreciation, and the exchange market instability induced by them. Because of historical institutional ties, and because the government is often politically incapable of reducing government spending or increasing taxes, financial institutions turned to the Fed for relief. But the ability of the Fed to fight inflation and protect the dollar is being seriously undermined just as the need for it to do so increased. The relative impotence of the Federal Reserve means that all sectors of American business now require new methods to fight inflation.

A great deal of evidence suggests that contractionary macroeconomic policy cannot reduce inflation in the United States without at the same time creating serious dangers. It seems, for one thing, that Marx's reserve army effect is becoming less and less powerful. Contractionary monetary policy results in large amounts of unemployment with relatively little reduction in wages and prices. ${ }^{40}$ This increases manufacturers' demand for inflation, but reduces the Fed's ability to satisfy the financial demands to stop it. In the recession of 1920-1921, for example, wage inflation fell by 37.4 percent and price inflation by 56.8 percent. In contrast, during the severe recession of 1973-1975, wage inflation increased by 2.9 percent and price inflation by 8 percent. This is the extreme case, but the same general pattern emerges for milder cases as well. ${ }^{41}$ One simulation of an econometric model of the economy showed that contractionary monetary policy would take until 1985 to reduce the inflation from 10 to 4 percent, but the unemployment rate would have to increase to over 10 percent. ${ }^{42}$ It seems highly unlikely that any political coalition could withstand that kind of austerity. Margaret Thatcher is attempting just that in the UK, and serious strains are showing after only a year.

The reasons for the reduced ability of unemployment to discipline workers are not completely understood, but a number of factors are probably involved. The use of Keynesian policy in the past to reduce the duration and severity of unemployment, and the expansion of social programs to reduce its pain, have probably reduced the willingness of workers to take wage cuts even in the face of unemployment. ${ }^{43}$ Even the benefits accruing to financial institutions from Fed inflation fighting are called into question. The very solvency of financial and nonfinancial corporations 
DOMESTIC STAGFLATION

begins to be undermined the higher interest rates go and the tighter credit becomes. Both inflation and economic expansion tend to reduce the liquidity positions of corporations. This results partly from the fact that inflation increases the tax advantages of using debt, partly because in a boom corporations are willing to take more risks, and partly because long-term debt becomes relatively more expensive the higher and more variable its inflation. In 1976, the ratio of liquid assets to current liabilities of nonfinancial corporations was 38 percent. By 1980 it had fallen by a quarter, to 28 percent, its lowest point ever. Over the same period, the ratio of long-term debt to short-term debt increased by a similar proportion. ${ }^{44}$ If the monetary authority attempts to stop the expansion by tightening the money supply and reducing sales, firms may find it difficult or impossible to pay back their debts. As Rapping puts it, the Fed can pull on a string, but only at the risk of breaking it. ${ }^{45}$

The OPEC oil price increases have enormously exacerbated the international financial dangers of attempting to fight inflation by creating a recession. In 1979, American banks had outstanding over $\$ 55$ billion in loans to Third World countries. ${ }^{46}$ Many of these were made to help finance oil imports. After the first major oil price increase in 1974, there was much speculation in the financial press on the ability of the private banking sector to take deposits of OPEC wealth and lend them to countries who needed to borrow in order to buy back OPEC's higher priced oil without a rash of bankruptcies ensuing. But most major American banks assured everyone that they could handle the job, and they did with minimal help from the IMF. This time around, however, it is virtually impossible to find a banker or bank regulator who thinks the banks can do it alone. As Volcker put it:

Although there is still some leeway, it seems to me, for reasonable increases in bank lending to these countries, one potential danger in the recycling process that we must avoid as far as possible is the overloading of the commercial banking system. ... If we urge [the Third World] to make real adjustments, they, in turn, will expect us to keep our markets open to their goods. ${ }^{47}$

If the banks are going to be repaid, the United States or other industrial countries will have to import billions of dollars of goods from these countries. Importing such amounts will be virtually impossible politically and economically if economic growth is not sustained. Protectionist pressures almost inevitably build if high levels of unemployment and low profits are maintained for long periods of time. Other countries would probably respond in kind. If trade wars are exacerbated, financial battles will be hard to win.

The roots of stagflation in the United States can now be discerned. Sustained economic expansion generates reduced productivity, higher costs, and demands for inflation; OPEC and domestic oil price increases 


\section{THE HID DEN ELECTION}

generate demands for inflation; and dollar devaluations increase demands for inflation-all to transfer wealth from American workers without eroding corporate profits. But inflation undermines financial markets and causes the dollar to depreciate. The latter in turn can generate great instability on foreign exchange markets because the dollar is still the linchpin of the international financial system, despite the great reduction of American power. Demands for relief from the "rentiers" pour in to the Fed, but while the Fed is able to generate high unemployment, before it can make a major dent in inflation it relents for fear of creating financial crisis. In the meantime, investment has been discouraged by high unemployment rates and tight money, which means that in the next round, productivity is damaged and the basis for noninflationary growth is undermined.

The standard economic theories no longer seem to hold much promise of solving the stagflation problem. Milton Friedman's view that the Federal Reserve should just reduce the money supply does not seem tenable. In the medium run such attempts can only damage powerful interests in the economy, and call into question its financial and political stability. In the long run, such control is virtually impossible. Yet Keynesianism, the major alternative, has been discredited. Economic expansion creates inflationary excesses, which, we have seen, also harm powerful interests and pose serious dangers. It is small wonder that a new theory, supply-side economics, which promises to sustain economic growth without exacerbating inflation, was embraced by the winning presidential candidate. It is also little wonder that that administration's promises can be fulfilled only if a noninflationary method to cut government social spending and workers' real income is discovered. Otherwise the Fed will have to rise to the occasion as it has in the past, to stem the "inflationary" excesses of government. Its ability to do so, however, is hardly a foregone conclusion.

\section{MONETARY POLICY IN THE HIDDEN EL E C T I O N}

Economic policy during the Carter years can be greatly illuminated with the help of the framework outlined in the previous section. During the Carter years, three different men were chairs of the Federal Reserve. The circumstances surrounding their appointments illustrate the contingent nature of the Federal Reserve's independence and the difficulties of maintaining that independence if the appropriate political constituency is not cultivated. The problems faced by the three, Arthur Burns, G. William Miller, and Paul Volcker, also suggest the difficulty of satisfying any constituency when the macroeconomic problems become increasingly intractable.

Despite the vulnerability of the Fed, however, the Carter years also show that its relative independence means that it is to the Fed that financial 


\section{OMESTICSTAGFLATION}

institutions and the president must turn for relief when the political process is too stymied to take charge. But the Carter years also show that increased international competition between the United States and Europe and Japan, the power of OPEC, the need to satisfy the demands of its financial constituency, the integration of international financial markets, and the power of labor at home and abroad greatly undermine the ability of the Fed to restore conditions of profitable expansion in the United States, much less help incumbents get reelected.

Jimmy Carter failed to reappoint Fed Chairman Arthur Burns in December 1977. The business press speculated that the reason was that Burns, the man of impeccable conservative credentials, having served as chairman of Eisenhower's Council of Economic Advisers (1953-1956), counselor to President Nixon (1969-1970), and head of the Federal Reserve beginning in February 1970, was on a collision course with Carter. Carter, the Democrat, had inherited a 7.4 percent unemployment rate from Gerald Ford and hoped to get it down. Burns would not go along, so he was fired.

The reasons for Carter's failure to reappoint Burns are considerably more complex. One would be simplifying only slightly by saying that Carter wanted to appoint someone who would fit in with the multinational business decor of his administration. ${ }^{48}$ For his part, Burns had abandoned his natural constituency, large bankers, and had alienated small bankers as well. Moreover, he was implicated in the massive recession of 1974-1975. Having lost support on all sides, when Carter chose not to reappoint him in December of his first year in office there were few cries of dismay, and no financial panic. Moreover, Burns's reputation as a tight-fisted monetary conservative was misleading in any case. As Rapping puts it:

[Burns] was the ultimate pragmatist: talking and acting conservatively by day and running the printing presses by night. Burns was a closet inflationist rather than a great liquidationist in the tradition of Andrew Mellon, Treasury Secretary in the early 1930 's. . . Burns did not pursue the Mellon policy quoted so vividly by Herbert Hoover. "Liquidate labor, liquidate stocks, liquidate the farmers, liquidate real estate. . . . It will purge the rottenness out of the system." ... With the advantage of historical perspective, Burns bowed to necessity as a more ideological and less pragmatic conservative might not have done. ${ }^{49}$

Burns's role was hardly benign, however. There were dramatic swings in the money supply during the early part of his tenure at the Fed from 1970 to 1974. The increase in rates of growth of both the nominal and real money supply during the two years from 1970 to 1972 is spectacular, as is the decline in the year and a half following. The latter preceded the worst recession the United States has experienced in the postwar period.

There has been a great deal of speculation concerning Burns's motivation in the extraordinary monetary expansion of 1970-1972. Much of it 


\section{THE HID DEN ELECTION}

has centered on the suggestion that Burns was trying to engineer Nixon's reelection. ${ }^{50}$ Rapping's implicit view that Burns was attempting to forestall a major financial panic resulting from the tight policies inherited from Martin is undoubtedly correct. But the policies to stabilize the financial markets in the wake of the Cambodian invasion in the spring of 1970 and the Penn Central collapse in the fall cannot account for the massive increases in the money supply over the next two years. Of more importance here was Burns's attempt to keep interest rates low during Nixon's wage and price controls in 1971-1973. As chairman of Nixon's Committee on Interest and Dividends, Burns was worried that Congress would attempt to control interest rates. He hoped to insulate the banks, and to avoid putting them in the undesirable position of experiencing a credit squeeze, on the one hand, or raising interest rates and bringing down congressional wrath on their heads, on the other. More important, however, was Burns's concern that rising interest rates would reduce political support for the wage controls which formed the basis of reestablishing American international competitiveness after the devaluation of the dollar in August 1971. A representative passage appears in the Federal Open Market Committee meeting in September 1972:

\footnotetext{
Chairman Burns [commented that] it was clear that the Pay Board would find it extremely difficult to lower the wage guideline if consumer prices, profits, and interest rates were rising rapidly and if the Committee on Interest and Dividends [of which Burns was Chairman] responded to pressures to relax the dividend guidelines. Assuming, however, that overall developments were of a kind that permitted the Pay Board to lower the wage guidelines, subsequent sharp increases in interest rates might well create problems. ${ }^{51}$
}

If wages increased after the devaluation, export profits would fall; if export producers raised prices, exports would not become competitive on world markets. In order to keep interest rates low, the Fed had to keep expanding the money supply in the face of strong demand for credit as the economy boomed.

The Fed's role in the major recession of $1974-1975$ is more difficult to assess. Though Burns has been blamed for the severity of the recession, the role of monetary policy was considerably less clear. The two major difficulties facing the Fed during the first OPEC price hike were its inability to forecast the effects of the hike, and its inability to forecast the effects of its monetary policy on the economy. The first was a general problem facing all the institutions attempting to deal with the massive disruption following the quadrupling of oil prices and the oil embargo. The second problem was the Fed's alone.

The difficulty facing the Fed was one manifestation of the general problem it has in controlling the money supply: the relationship between the amount of money it puts into the economy and the effects of that 


\section{O M EST I C T A G F A T I O N}

money on the economy is subject to erratic shifts. These shifts are due to the invention of new kinds of money over which the Fed has no control. Prime examples of new money are credit cards and money market funds (which are like checking accounts) created by brokerage houses. When new money is created, it will affect the amount of spending in the economy. If the Fed does not know how much has been created, it does not know how much money it should create through its own policy. Such a major shift occurred during 1973-1974. In fact, its cause is still not completely understood. But the shift created massive uncertainty for the Fed, which made it difficult to make policy and extremely difficult to judge its intentions from the effects of its policy. It is undoubtedly true that the Fed was not willing to let inflation run rampant. But it probably ended up with a much more restrictive policy than it bargained for, and contributed much more to the major recession than it intended.52

The widespread perception that the Fed had major responsibility for the recession, however, generated bitter congressional criticism. In March 1975 Congress passed a joint resolution calling on the Fed to reduce interest rates, to announce annual growth targets for the money aggregates, and to appear periodically before the appropriate congressional committees. While the congressional oversight of monetary policy has little direct impact on policy, passage of the bill represented movement toward less independence for the Fed. The effects of the great contraction bear most of the responsibility for the passage of the congressional oversight. But Burns's premature attempts to centralize the Fed, even further reducing the powers of the Regional Reserve banks and the smaller banks they represent, undermined the Fed's traditional base of support in Congress, which might have been able to fight off the attack. Burns, for example, apparently attempted to use Reserve Bank budgets and staffing limits as a means to affect the research of the Reserve Banks. And on one occasion he tried to prevent and then alter the testimony of Reserve Bank presidents before the House committee on banking and currency. ${ }^{53}$

So when push came to shove, Burns had lost allies on all fronts. He was implicated in the destruction of the Bretton Woods system, which disrupted the relations between the United States, Japan, and Europe, alienating the multinational business community; he was blamed for the recession; he had allowed the independence of the Fed to be eroded; and he had alienated small bankers as well. As it happened, Burns did not attempt to slow the growth rate of the economy. Except for some threatening increases in the federal funds rate in the fall of 1977, Burns pursued a middle course. During 1977, the economy grew at an annual rate of 5.3 percent and employment grew by 3 million people. The rate of growth of real hourly earnings declined, raising both the share of profits in income slightly and the after-tax rate of profit as well. Toward the end of the year, the depreciation of the dollar became worrisome, especially since the trade deficit was not improving. But that was to turn around early in 1978 .

Miller took over from Burns in March 1978 and proceeded to ensure 


\section{THE HID DEN ELECTION}

that the recovery would not falter. "I'm going to be concerned with keeping the economy going and not having a recession. I am going to run it for human beings," Miller said in December. ${ }^{54}$ Real per capita spendable income did increase by 3.8 percent in 1978, the fastest rate since 1973. But that resulted from more people working, not higher hourly wages. During the year, real compensation per hour declined even though productivity increased by almost 2 percent. Indeed, the vast expansion of the labor force in the midst of relatively small increases and even declines in real wages goes a long way toward explaining the ability of the United States to sustain growth over the long 1976 to 1979 period. The increase in the labor force resulted not only from demographic factors, the baby boom, and social factors such as the increased desire of women to work outside the home; it also resulted from the need of extra workers to find paying jobs to support their families in the wake of slower economic growth of the late 1960 s and early 1970 . This increase in the potential "reserve army" was critical to the ability of the United States to expand without running into the barriers of worker militancy and higher wage demands. Between 1976 and 1980, employment in the United States grew by 11 percent, while in Japan the figure was 5 percent and in Germany 3 percent, the next two largest increases among industrialized countries. ${ }^{55}$

And the expansion was having its intended effect on OPEC's surplus. OPEC's current account surplus declined by $\$ 20$ billion, the largest decline since 1975 . The 1978 reduction resulted primarily from the deterioration in OPEC's aggregate terms of trade (which are the price of its exports relative to the costs of its imports). During 1978, OPEC as a group experienced an 11 percent decline in its terms of trade relative to 1977. Of the total 15 percent increased cost of imports to OPEC, over half reflected the depreciation of the dollar against major currencies; the rest stemmed from inflation in the industrial countries. The terms of trade facing OPEC in the fourth quarter of 1978 were 23 percent less favorable than they had been in 1974. OPEC's surpluses also fell partly because oil exports declined because of conservation measures by Europe and Japan. Exports also declined because European economic growth had not recovered since the 1974-1975 contraction. While real GNP in the United States was growing by 5.3 percent in 1977 and 4.4 percent in 1978 , the European countries were growing at 2.3 and 3 percent, compared to their 1963-1972 average of 4.5 percent. ${ }^{56}$

Despite Europe's failure to grow as rapidly, dollar depreciation was finally also having its intended effect on the U.S. trade balance. It improved by $\$ 5$ billion in 1978. But in September 1978, concern for the dollar finally began to take its toll in the Fed's decision-making body. In September Henry Wallich, one of the Fed's major spokesmen on international monetary matters, dissented on the side of tightness for the first time during the Carter administration. From September 1977 to September 21, 1978, the dollar fell by more than 56 percent against the Swiss franc, 42 percent against the yen, and 19 percent against the German mark. The Fed raised 
D OMESTICSTAG F LATION

the discount rate toward the end of September as a first step to strengthen the dollar. In October, Carter unveiled a new "anti-inflation" program, including voluntary wage and price controls, in an attempt to prevent workers' wages from catching up with the depreciation-induced inflation that two years of economic expansion had created. The exchange markets were unimpressed, however. The dollar fell almost 2 percent the last few weeks in October.

The dollar was declining despite an increase in American interest rates, an improvement in the trade balance, and a rate of inflation that was in the middle ranges of European inflation rates. The view taken by the administration and numerous economists was that the dollar was undergoing an irrational speculative attack, a view which has an important element of truth. Free markets that have as their object the accumulation of profit are not likely to be stable when the world has nothing solid on which to base expectations. Uncertainty breeds speculation.

The uncertainty was generated, however, by real factors of great significance. First was the recognition that OPEC was not likely to continue playing the fool to the American game of using inflation to erode its wealth. Second, Europe was creating the European Monetary System (EMS), partly in response to the dramatic declines in the dollar over the previous year. Some feared that the EMS would lead to a currency bloc competing with the dollar as a reserve currency, and therefore for holdings of OPEC surpluses. Finally, European countries were less reluctant to support the dollar as they began to see the benefits from appreciating currencies, both in terms of lowered inflation and in terms of increased profits for their financial institutions.

To prevent the position of the dollar from eroding further, the Fed and the Treasury, on November 1 , made it clear that, after almost a five-year hiatus, they would again begin to defend the dollar's role. The Fed raised the discount rate by a full percentage point, the largest amount ever, increased reserve requirements on large banks, and sold bonds denominated in yen and marks to sop up excess dollars in the foreign exchange markets. The measures temporarily staved off the speculative fervor. But in December oil exports were halted from Iran, and OPEC announced a 14.5 percent increase in the price of crude oil to be phased in over the next year. The OPEC price increase and the revolution in Iran exacerbated the Fed's problems, which had been mounting in any case. At the beginning of 1979, the Federal Reserve and the international team within the administration and their allies were badly divided on the proper course of action. Within the Fed, Paul Volcker, president of the New York bank, dissented for the first time in March and April, calling for tighter policy. Wallich joined him. ${ }^{57}$

Meanwhile, Blumenthal and Miller were openly fighting. In April, as the dollar continued to fall, Blumenthal was calling for tighter policy, while Miller expressed "satisfaction" with the current degree of restraint. ${ }^{58}$ Miller received support from welcome quarters. As the controversy 


\section{THE HID DEN ELECTION}

swirled, David Rockefeller, chairman of Chase Manhattan Bank, gave a rare on-the-record speech at the bank's annual Washington dinner-press conference on April 18, 1979. Rockefeller said: "Miller 'correctly' had opposed 'dramatic' changes in Federal Reserve Policy. . . . The New York bank executive noted that at the end of the last expansionary period, tightening produced a 'harmful crunch.' " Presumably he was referring to Burns's policy in $1974 .{ }^{59}$ To make sure there was no mistaking his concern, however, Rockefeller reportedly "Praised the administration's November I dollar support program. 'It has demonstrated to dollar holders that this country is prepared to support the dollar.' "60 Since the dollar was still holding up against other currencies in April, a majority of the Fed and Miller did not want to risk a credit crunch as long as inflation was helping to reduce real wages to pay for oil. In 1979 , real wages fell by $\$ 45$ billion, enough to pay for the higher cost of imported oil. ${ }^{61}$

During the summer, in an attempt to rescue his reputation and the election from the jaws of OPEC, Carter reorganized his cabinet. Having fired born-again interest hawk Blumenthal, Carter needed someone whose very presence could maintain the confidence of the foreign exchange markets. Worried that a feverish dollar speculation could undermine the whole international system, Carter had hoped to prop up the dollar with psychological warfare on the exchange markets in lieu of real warfare on the electorate. The president turned to Paul Volcker, president of the New York Federal Reserve, a former undersecretary of the Treasury who had been involved in the monetary negotiations of the early 1970s, and a former vice-president at Chase Manhattan. Volcker became chairman of the Fed in August. Miller, whose credibility on the exchange markets had been sacrificed to the economic expansion, became secretary of the Treasury. The expansion had gone on, apparently, a bit too long. Roosa exclaimed that "Volcker is absolutely the right man and I'm delighted."62

Reputation is quickly depreciated. The money supply continued to grow at a rapid pace, as American banks borrowed billions of dollars from their banks in the Eurodollar markets. In September, silver and gold prices skyrocketed and the value of the dollar dropped substantially, despite intensive intervention by the United States on the foreign exchange markets. By the end of September, all proceeds from the sale of the yen and mark bonds the previous year had been exhausted, and foreign exchange borrowed from the Germans was running out. At that point, the Germans were apparently approached to see if they were willing to extend more credit so that the Federal Reserve could continue carrying out its dollar support operations. But the Germans proved uncooperative. Morgan Guaranty reports:

The discussion apparently ended with agreement by the German and U.S. authorities that continued heavy central bank intervention alone was not the answer to the dollar-mark problem. Instead, more fundamental action 
DOMESTIC STAGFLATION

to curb inflationary pressure in the United States was needed to arrest the dollar's decline against the mark and to curb speculation in gold and other commodity markets. ${ }^{63}$

Since the European central banks were unwilling to intervene heavily in the exchange markets, Volcker rushed back from an international monetary conference to a secret meeting in Washington. On October 6, the Fed announced a series of restrictive measures, including a percentage point hike in the discount rate to a record 12 percent (now almost an anachronism), an increase in reserve requirements on a range of managed liabilities, and most important of all, a new monetary management technique.

Volcker chose a meeting of the American Bankers Association to unveil his new policies. "Whatever the Fed had in mind," Volcker said, the Fed's moves "Weren't designed to make your life as bankers easier." ${ }^{14}$ But the big bankers did not seem to be complaining. Willard Butcher, president of Chase Manhattan, said: "It will tend to deepen what has been seen as a relatively shallow recession but is a price worth paying. Inflation is a terrible cancerous disease that takes radical action." ${ }^{\prime 65}$ However, the disgruntled president of a small Southwestern bank said: "Once again the banking system has been called upon to make sacrifices while other segments of society roll merrily along." 66 Just as small bankers are hurt most by inflation, their inflexibility means they lose more when the Fed takes dramatic action. By reducing the money supply, the Fed reduces the resources at the disposal of small banks. Large banks, on the other hand, are often able to get resources anyway by borrowing from large corporate customers. Neither do small banks benefit from the international effects of the Fed's policies, since they tend not to participate in international lending.

One policy change was of special significance. Volcker announced that the Fed would stop trying to control interest rates to stabilize the money supply. Instead, it would let interest rates fluctuate and try to control bank reserves directly. The Fed claimed this policy would give it more direct control over the money supply, but its real motivation was different. The Federal Reserve needed to take dramatic action that would calm the nerves of the money and commodity markets. Moreover, it knew that, if it were to maintain the value of the dollar and the health of the financial markets, the Federal Reserve might well have to take contractionary policies which would drastically increase interest rates. Yet interest rates are highly visible and politically dangerous for the Federal Reserve and the banking community as a whole.

When interest rates were so politically sensitive during Nixon's wage and price controls, and Burns would not raise the Federal Reserve discount rate to help the banks raise their primes (see below), some major banks invented a prime free of human intervention. The prime rate, they said, would be set by a formula which would tie the prime to their cost of funds. 


\section{THE HID DEN ELECTION}

"We married ourselves to the market-for better or worse," said E. E. Palmer of Citibank. ${ }^{67}$ But the prime rate still went up faster than it came down when the cost of funds varied, raising questions about the sanctity of the marriage.

The Fed's desire to marry the market and insulate itself from political pressure during the election year (and in general) undoubtedly played an important role in the decision to target bank reserves rather than interest rates. But letting interest rates fluctuate wildly to reduce political opposition probably created more problems than solutions for the Fed. Some studies have shown that widely fluctuating interest rates create uncertainty and discourage investment. Moreover, fluctuating interest rates create risks for those investing in dollar-denominated assets that could hurt the value of the dollar even further in the long run. By October, the Federal Reserve and the credit markets were running the economy. The Wall Street Journal reported in November:

The Carter administration has made little comment since it formally endorsed the new policy. One policy maker commented that the President would like to put a little distance between himself and the Fed but will not outrightly criticize that body fearing it could hurt the dollar on the foreign exchange market. ${ }^{68}$

Even the opposition could not attack the Fed. In an interview with Business Week in October, Kennedy was asked whether he approved of the Federal Reserve's recent steps. He replied:

One of the leading problems in the country at present is inflation. The steps the Fed has taken are not steps that I would differ with, although we have to monitor this action extremely closely over the next several weeks to see whether it will put us over the brink and into a more serious recession. ${ }^{69}$

Meanwhile, in December, Lelan Prussin, vice-chairman and world banking chief of Bank of America, reported that the Fed's moves are "working fine. Credit demand has slowed, aggregates are declining, and there's much more discipline." 70

In January 1980, OPEC crude oil prices increased 9.5 percent, and the second phase of domestic decontrol of oil prices went into effect. By March, domestic oil prices had doubled from a year earlier and OPEC prices had more than doubled. ${ }^{71}$ The economy officially went into a recession, probably brought on by the October 1979 policies. ${ }^{72}$ But the Consumer Price Index went up at an annual rate of 17.5 percent, significantly greater than the 12.6 percent increase of December. Productivity took a mysterious drop in the last quarter of 1979 and first quarter of 1980 , wages began to rise rapidly, and unit labor costs began to increase at a rapid pace. Interest rates began rising as well, partly in response to the expectation 
DOMESTIC STAGFLATION

that, in the wake of Iran and Afghanistan, military spending and inflation would take off.

By the end of February, influential Henry Kaufman, general partner of Salomon Brothers, an investment bank, was widely quoted as believing that a national inflation emergency should be declared which included a

temporary wage and price freeze or a simple mandatory controls program provided they were joined with cuts in government spending and limits on government and private borrowing. ${ }^{73}$

In an article in The New York Times on February 27 entitled "Price Controls Gaining Friends," Leonard Silk reported:

\begin{abstract}
A growing number of critics contemplating $18 \%$ inflation, possible destruction of the bond market or even an end to the democratic system, as Business Week warned, have become convinced that controls might be necessary ... with the only alternative being a major and prolonged recession, controls have become more and more acceptable except to a few tenured academic economists. ${ }^{74}$
\end{abstract}

But Paul Volcker, in testimony before the Senate banking committee, said that controls would not be useful against inflation. He warned that they would "divert attention from what really needs to be done," reduction in American dependence on OPEC and cuts in government spending. ${ }^{75}$ Kennedy came out for a six-month freeze on wages and prices, and calls for consideration of controls came from Robert Byrd and William Proxmire. Yet on February 26, Carter called controls "counterproductive," and said he did not see any prospect at all of supporting them..$^{76}$ Those are the words of someone opposed to controls and someone who is planning to implement them but does not want panic price and wage increases to undermine them before they are in place.

There are some indications that a number of Carter's political advisers were recommending controls. Controls could have saved Carter from a spiraling inflation and recession at election time. The New York Times was even speculating that controls would return soon after Kennedy was no longer regarded as a threat. But as Representative Weiss (D, NY), a leading proponent of controls, reported in late February:

Sentiment is shifting [in Congress] but it is still very slow. The Republicans have done a very good job brainwashing the Democrats, convincing them controls don't work. ${ }^{77}$

Even the financial community was divided. On March 6, Leif Olsen, chairman of Citibank's economic policy committee, wrote in The Wall Street Journal in an article "Fear Rules the Credit Markets" (presumably a reply to Salomon Brothers' Kaufman): 


\section{THE H I D E N ELECTION}

The fear that grips the credit markets will lead to self-destructive advocacy of wage, price and credit controls it has traditionally and wisely opposed in the past. . . .78

By this time, Walter Wriston, president of Citibank, had endorsed Reagan. And Citibank was worried that credit controls would be slapped on, costing it millions of dollars in loan interest.

On March 4, The New York Times reported that John Dunlop, the Harvard professor who had directed the administration's Pay Committee, composed of business and labor leaders, had made a bid to increase the scope of the committee to include such issues as "capital formation, trade policy and credit policy," which Congress seemed unable to deal with. Instead, Paul Volcker and the Federal Reserve took control again.

Wage and price controls might have saved Carter. But he did not want to seem to vacillate, and his major economic advisors were opposed to controls. Congress was unlikely to support controls for good reasons: oil prices were a major driving force behind inflation, and controls could not affect them. Moreover, wages were not keeping up with inflation as it was, so if controls were to help stop inflation, they would probably only have hurt business profits. In the end, Carter had only the Fed to turn to. And turn he did. On March 14, Volcker announced new measures to put an end to the "fear" that had gripped the bond markets. He announced that the Federal Reserve would implement the president's credit controls. The controls placed limitations on the extension of new consumer credit through credit cards, and put reserve requirements on money market funds. Money market funds were not subject to interest ceilings and had bid away billions of dollars from savings and loans and commercial banks. The controls were slapped on despite the fact that the rate of growth of consumer credit had been falling for virtually the entire previous year. ${ }^{79} \mathrm{~A}$ congressional investigation later contended that credit controls had helped many banks raise terms on credit cards, on which they had been losing money. They had been reluctant to change the terms themselves for fear of losing out to the competition. Regulations like these often serve to help financial institutions coordinate their pricing, while at the same time performing a macroeconomic function for the Federal Reserve.

Over the next month, interest rates and the dollar skyrocketed. The money supply took a nose dive. Between April and June, real GNP fell at an annual rate of almost 10 percent, the largest quarterly decline on record. And along with it, interest rates and the dollar plunged. The prime rate fell from a high of almost 20 percent in April to 12.5 percent in July. Other interest rates fell even more. The press reported that the economy was in a free fall, and the Federal Reserve madly attempted to reverse itself. In June, the money supply grew at an annual rate of almost 14 percent, and at 11 percent in July..$^{80}$ But by that time unemployment had taken off; by July it was at 7.8 percent. The Fed was reluctant to reverse itself too quickly, however, since the dollar had lost much of the ground it had 


\section{O MESTICST A G F A T IO N}

gained. Anthony Solomon, former undersecretary of the Treasury, who had replaced Volcker as president of the Federal Reserve Bank of New York, cautioned against too precipitous a decline in interest rates and the dollar. ${ }^{81}$

For its part, the administration was letting the government budget become more expansionary. The high employment deficit, which measures how expansionary the government budget is, moved from $\$ 2.2$ billion in 1979 to over $\$ 21$ billion from April to June 1980 and to $\$ 20.7$ billion from July to September. Part of this expansion resulted from technical procedures involved in measuring the deficit, part from increased unemployment and other payments associated with the recession. But on the basis of the available evidence, it seems unlikely that the administration was trying to impose contractionary policy; it probably was attempting to pump up the economy. Meanwhile, congressional Democrats and Republicans were competing to see who could come up with the quickest tax cut proposals in the face of the perceived economic free fall. Carter cautioned them against ill-conceived proposals, especially those directed toward individuals. He came up with his own plan, "the economic revitalization program," which stressed corporation tax cuts, including those for the declining sectors of steel and auto. Volcker warned that tax cuts, especially personal ones, were inflationary in the current environment, and suggested that he would not accommodate them unless government spending were reduced. If Volcker raised interest rates sufficiently, he could nullify their expansionary effects.

After a 21.6 percent increase in the money supply in August, the Fed reduced the rate of growth of the money supply in the two months before the election. In the last week in September the Fed tried to tighten up even further. On September 26 it raised the discount rate by a full percentage point again. As Volcker put it later:

We had to recognize that the already precipitous decline in interest rates might be misread as a fundamental reversal of policy ... a lessening of our resolve to fight inflation. Such a false interpretation could only have undermined the ultimate success of that effort ... [and] could have complicated our task further by undermining confidence in the dollar on foreign exchange markets $\ldots$ as it turned out $\ldots$ that $\ldots$ was avoided. ${ }^{82}$

But by September, Carter was fighting for his life. He and his advisors complained that the Fed's discount rate hike was unnecessary. Fuel was added to the fire when the commercial banks, led by Reagan supporter Walter Wriston's Citibank, began raising their prime rates. They jumped from II percent in September to 13.5 percent by the end of October. Even Volcker began to worry that such massive increases in the weeks before the election stretched the limits of political etiquette. In his own defense, and apparently in a politically safe jab at Wriston, Volcker explained: "There's a tendency for markets to jump and I wonder if they haven't 


\section{THE HID DEN ELECTION}

jumped too far." But by October, it was simply a waiting game. The overall unemployment rate had risen to 7.6 percent, virtually as high as it had been when Carter had beaten Gerald Ford four years earlier. The bluecollar unemployment rate was a full percentage point higher at 10.8 percent, and the black unemployment rate had risen from 12.7 percent in 1976 to over 14 percent in October 1980. And inflation was still 5 percent higher.

After a respectful pause during October, the Fed began to respond again to the real underlying pressures. Between November and the end of December, the prime rate skyrocketed to 21.5 percent with a 2 percent increase in the discount rate leading the way. This time Carter was not complaining. But the newspaper headlines blamed high interest rates for the failure of auto sales to recover. The old conflicts were not about to fade away with Jimmy Carter, nor are they likely to in the face of the supplyside mystification and wishful thinking of the Reagan team.

\section{MACRODILEMMAS: THE HIDDEN ELECTION AND BEYOND}

The three main economic problems facing the American economy are the declining growth of productivity, the massive increases in oil prices, and the increased international competition facing important sectors of its industry. I use the term "American economy" advisedly: These are problems that affect the vast majority of American citizens, but big business is using them to mobilize support to solve its own difficulties.

The major economic problem facing the big business community is how to increase the profitability of major American financial and nonfinancial institutions without continuing to impose burdens on each other, and at the same time without undermining political stability at home. ${ }^{83}$ The more the burden can be placed on the Third World, OPEC, Europe, and Japan, the less they have to put on small business and workers at home. While shifting some of the burden to foreigners is a necessary part of any viable strategy, the reduced power of the United States in the world economy and increased competition from abroad means that restructuring at home is unavoidable if the stagflation impasse is to be broken. And to conduct that restructuring, a policy of economic and political obfuscation and further reduction of democratic control over the economy will have to be pursued. Increasing the power of the Federal Reserve is a prime component of this strategy.

On the domestic side, the success of that restructuring will depend on the ability of corporations to get the government to force consumption and real income losses on the majority of the American people without resorting to inflation, which undermines financial markets and the international monetary system. Already the business press is pointing out that "break- 
DOMESTIC STAGFLATION

ing inflationary expectations" will be one of the major problems facing the Reagan administration. These expectations are simply workers' waking up to the fact that almost 8 percent of their incomes have been lost in the last two years, with the expectation that they might be able to make some of it up. Increasing productivity is the key to the domestic strategy of increasing corporate profits and the international competitiveness of American business without imposing significant costs on the financial sector. If productivity increases, and workers' wage demands do not match that increase, manufacturing profits can increase without a resort to inflation and international competitiveness can be improved without having to rely on the depreciation of the dollar. Reducing taxes to corporations and the wealthy are further ways to redistribute income. But if tax cuts are not matched by increases in productivity or reductions in government spending, then inflation results, imposing the old dilemmas once again.

Arthur Laffer's supply-side economics, which was embraced by Ronald Reagan, appeared as a possible way out of this dilemma. According to Laffer's argument, individual income tax cuts would restore the individual initiative high taxes had muted. If people were subjected to lower tax rates, so the theory went, they would work more, save more, and invest more. All this, according to Laffer, would increase production and productivity. The biggest miracle of all was that supply and income would go up by so much as a result of these cuts in tax rates that the actual amount of taxes collected would actually stay the same or increase. Thus, the government budget would not have to be cut at all to avoid increasing the deficit or fueling inflation.

At one level, Laffer's supply-side economics is simply an attempt to redistribute income toward the rich. In the fifties, only one-third of the government budget was spent on transfer payments. By the early 1970s, two-thirds of the government budget consisted of transfers. The after-tax, after-transfer distribution of income is virtually the same now as it was at the end of World War II. But without these and other government programs, the distribution of income would have been considerably less equal. Tax cuts directed toward the rich and cuts in spending programs designed to help the poor are a thinly disguised exercise to reverse this.

Even on its own terms, however, there is at least one basic problem with supply-side economics: it has no foundation in fact. The pillar on which there seems to be the most evidence concerns savings. Supply-siders say that reducing taxes will increase saving and investment. There is little evidence that more saving produces more investment; the sequence is more likely to be the reverse. But what is at issue here is whether increases on the returns to saving will even increase saving. Stanford economist Michael Boskin published a very influential article in 1978 which, contrary to much previous evidence and conventional wisdom, purported to show that high returns to saving did in fact increase the amount saved. But many economists have complained that they have tried but failed to replicate his results. One even sent his results to Boskin, asking him for comments on 


\section{THE HID DEN ELECTION}

the paper. After more than a year and a half, he still had not heard from him, nor had he been able to get his paper published. The implicit argument in Boskin's paper that taxes should be lowered for wealthy savers remains in the public domain as justification for tax cuts for the rich.

Laffer's supply-side economics also assumes that increasing wages after taxes will increase the labor supply and raise productivity. But the experience of the 1970s suggests that the stick works much better than the carrot to increase labor hours, and in any case, such increases are unlikely to help restore productivity growth. As I suggested earlier, between 1976 and 1980 employment in the United States increased by a phenomenal II percent. That increase of the "reserve army of labor" was significantly responsible for the ability of the 1976-1979 boom to last. Moreover, that expansion was at least partly due to the need of families to increase the number of wage earners simply to keep their standard of living at a constant level. And although the expansion helped to maintain the boom, it also created problems. While the ratio of investment spending to GNP remained at almost the same level between 1974 and 1979, as it had between 1959 and 1969 (as opposed to many commentators who argue that the United States does not save and invest as much as it used to), the rate of growth of the ratio of the capital stock to hours worked fell from a 3.3 percent rate during the earlier period to only 0.2 percent during the 1974-1979 period. The decline was not as significant in manufacturing as it was for the business community as a whole, but it was significant there as well. Generally a decline in the amount of capital that workers use reduces the amount of output each can produce. And although the reduction does not explain all the productivity decline, it is at least as and probably much more important than government regulations, taxes, and spending. ${ }^{84}$ The reduced productivity that results from increased supplies of labor does not bode well for the ability of supply-side economics to stop inflation without lowering real wages.

Even the wealthy advocates of supply-side tax cuts embodied in the Kemp-Roth bill doubt its ability to slow inflation. They have suggested a return to the gold standard to go along with it-a monetarism that sticks. The essence of a gold standard is that the supply of gold will determine the money supply. Not trusting the political will or desires of the Fed, advocates favor rule by the market rather than by politics. The gold standard would supposedly maintain discipline on the economy and bring the money supply and inflation under control. If a gold standard were established in combination with tax cuts for wealthy individuals and a reduction in government spending for the poor, rich rentier incomes could not be eaten away by inflation and the United States would become a virtual individual rentier paradise, or so the thinking goes.

But the bulk of corporate America, including the large financial community, is more concerned with the stability and growth of their institutions on a world scale. Tax cuts, they say, should be for corporations, not 
D OMESTIC S TA G LA TION

for individuals. Individuals are just as likely to increase consumption as to increase saving. Monetary policy should be firm, but flexible. For them, Paul Volcker would probably be better than a gold standard. As undersecretary of the Treasury during the dollar troubles of the early 1970s, among American negotiators Volcker was reportedly the last to abandon convertibility of the dollar to gold and the most insistent on returning to gold at the earliest opportunity. If Volcker can maintain the relative autonomy of the Fed, he can be Reagan's gold standard, but a more flexible one to salvage the financial structure from a debt recycling or tight money collapse. The preferred strategy of the financially oriented supply-side Republicans is to couple corporate tax cuts with tight monetary policy and cuts in social spending.

Faced with a situation in some ways similar to the one confronting the economy today, the Kennedy administration devised a corporate investment tax cut to stimulate investment that was being discouraged by high interest rates maintained by the Fed to protect the dollar. The motivation is the same this time around. The mix of tight money and a corporate tax cut is designed to protect the dollar, as were the taxes in the early sixties; they are also designed to squeeze the housing industry, despite vast increases in family formation expected over the next decade. By reducing resources devoted to housing "consumption," corporate supply-siders hope to redirect resources devoted to excessive housing to the corporate sector to help offset the detrimental effects of tight money on manufacturing corporations. While they insist that only resources devoted to excessive housing speculation will be transferred, such fine tuning seems highly unlikely.

The major battle on the domestic side will involve the attempt to slash social spending to make way for corporate tax cuts and high defense spending. If this attempt is not successful, then Volckerism-tight monetary policy-will have to step in to stem the inflationary tide. But that can only lead back to the stagflation impasse. Redistributing income at home might help to alleviate problems facing business and might even generate some greater investment and productivity gains. But further domestic and international action will have to be taken to protect American business from international competition, to preserve the role of the dollar, and to protect the integrity of the international financial system in the wake of OPEC.

A prime example of the response of American business and its protectors to increased foreign competition is the financial community's new turn toward domestic restructuring with the help of the government and the Federal Reserve. In the spring of 1980, as the Federal Reserve was desperately trying to get the money supply, interest rates, and the dollar under control, it was winning a major political battle in Congress. On March 5, eleven days before the Fed's March action, the Senate and House resolved their differences on major financial reorganization legislation in a "whirl- 


\section{THE H ID DEN ELECTION}

wind conference.' "'85 Just a few days before, staffers on the Hill were bemoaning the difficulty of reaching agreement on the major differences between the House and Senate versions.

On March 31, President Carter signed into law a "far reaching" banking bill he had singled out as a key component of his new anti-inflation program. At a White House signing ceremony, Carter called the legislation a "significant step in reducing inflation" and a "major victory for savers.' "86 Senator Proxmire, chairman of the Senate Committee on Banking, Housing and Urban Affairs, referred to the bill as the most significant banking legislation since the passage of the Federal Reserve Act of 1913. The legislation that generated so much excitement was the Depository Institutions Deregulation and Monetary Control Act of 1980. In essence, the bill represents the culmination of a sixty-year struggle by the Fed to bring all depository institutions under its jurisdiction. Seemingly unrelated, but in fact of integral importance, the bill makes major strides toward pushing thrift institutions (savings and loans and mutual savings banks being the most important) into direct competition with commercial banks. The effects of that competition may well be to render appropriate one opposition senator's name for the bill, "The Depository Institutions Abolition Act." ${ }^{\prime \prime 7}$

The Fed pushed the bill as being necessary to bring the money supply under control. The bill will in fact help, since it will give the Fed more control over and better information about all banks in the system. However, the significance of the bill lies less in the reserve requirements which will be imposed on all depository institutions than in the intense domestic financial competition it will allow. The large banks' pressure for the bill and its ultimate importance can be understood only in the context of the increased domestic and international competition which large American banks have felt since the early 1960 s and the increased danger of international transactions since the OPEC price increases of 1974 and 1979. Both have heightened the urgency with which the large American financial institutions and their regulators have pushed for restructuring domestic financial competition.

The small commercial banks represented by the Independent Bankers Association of America (IBAA) and the small thrift institutions represented by the U.S. League of Savings and Loans Associations were adamantly opposed to the bill. Speaking of an earlier version of the bill in the House and Senate, a representative of the IBAA said: "Nothing is acceptable in either of those bills. . . The way the bills are structured, there's nothing in it for us." Indeed, the small banks, having significant power in the House, were able to stop Federal Reserve attempts to make reserve requirements mandatory, even after the House Banking Committee had supported the Fed. "People tend to listen to what their community banker says," one financial community lobbyist said. "They have a very good feeling for what's happening in the community and their connections are very good." The small bank lobby seemed so strong, in fact, that the 


\section{DOMESTICSTAG F L A TIO N}

Federal Reserve backed down considerably. It was even willing to accept a bill that would have substantially reduced the number of commercial banks under the Fed's control if the erosion in Federal Reserve membership were at a slower rate than the Fed was predicting.

Yet by March the power of the small banks and thrift institutions in Congress had been virtually broken. With the financial markets on the verge of panic, Paul Volcker and the Federal Reserve were more and more seen as the only hope. As a result, Jimmy Carter and Paul Volcker were able to take another giant step down the path traveled by J. P. Morgan and Benjamin Strong toward a centralized banking system that could better compete with the centralized banking institutions of Europe, Japan, and the OPEC countries.

The competition facing large American banks both at home and abroad has been substantial in the last decade. Money market funds offered by brokerage houses have attracted billions of dollars in deposits away from the nation's commercial banks and savings and loans. On the loan side, the commercial paper market, by which corporations bypass the banks and lend directly to one another, has become a significant competitive factor. Even more worrisome has been the influx of foreign banks into the United States. Until recently, these banks were not subject to Federal Reserve requirements. Moreover, they were not prohibited by the federal government from setting up full-service branches across the states, while American banks, generally, are not allowed to engage in interstate branching. The growth of these banks in relation to the large American banks has been rapid. Between November 1972 and May 1977, the assets of foreign banks increased 175 percent, while assets for the large American banks increased only 40 percent. Concomitantly, the share of the foreign banks in large bank business in the United States increased from $\mathbf{5 . 2}$ percent in November 1972 to 10.4 percent by May 1977. Seventy-five percent of foreign bank corporate loans were made to domestic borrowers. ${ }^{88}$

One of the most obvious manifestations of the increased competition facing American banks has been the erosion of one of their main methods of fixing interest rates-the so-called prime rate convention. The prime rate is the rate of interest the large banks charge their most creditworthy customers. Essentially, the prime rate is a signaling device by which the large banks fix prices. Such price-fixing can work as long as the political process and the competition tolerate it. Since the early 1970s, both conditions have been significantly changed. Political toleration depended on the willingness of the Federal Reserve to protect the price-fixing by shielding prime rate changes with similar changes in the Fed's discount rate. Market toleration depended on the relative absence of competitive sources of corporate loan funds.

The importance of Federal Reserve support for the prime rate convention can be most clearly seen from the differences between two similar 


\section{THE HID DEN ELECTION}

events: prime rate changes under the Martin Fed during President Johnson's wage-price guideposts of the early 1960 s and prime rate changes during the Nixon wage and price controls under the Burns Fed. In December 1964, several banks boosted their prime rates, but in response to pressure from Johnson they rescinded the boosts two days later ${ }^{89}$ By the fall of 1965 , the members of the Martin Fed who were most concerned about the detrimental effect of the economic expansion on the balance of payments wanted to tighten monetary policy. They wanted to increase the discount rate to signal to the international currency markets that the Fed was serious. There was, however, another consideration in their desire to raise the discount rate. As Sherman Maisel, a member of the Board of Governors during this period, tells the story:

But a more critical factor was the desire to aid the banks in breaking President Johnson's stranglehold on the prime rate. As part of his general desire for low interest rates and his guidepost policy, President Johnson had forced banks to maintain a low prime lending rate. Since the banks wished to avoid a political battle with the President, some Board members felt that it was up to the Federal Reserve to oppose him in order to avoid a threatened inflationary increase in bank credit. $^{90}$

The discount rate was raised, the prime rate was raised, and there was a political battle. But this time, the rates stuck.

During Nixon's wage and price controls, however, Burns was primarily concerned to keep the prime rate down in order to protect the wage controls from political pressure. As a result, the large banks abandoned the prime rate convention based on following the signals given by the Fed. A number of the banks created formula primes, rates set by "the market," not by the banks. Although the convention had not been murdered by political battles of the early 1970s, it had been badly wounded.

The death blow will be dealt by the market. Corporations can borrow from one another and from foreign banks, in the United States or in the Eurodollar markets. The ability of the banks to make the prime stick, even when they have the political will to establish it, has been seriously undermined. As market interest rates began their rapid descent after the March 1980 action, the banks tried to keep the prime rate from falling as rapidly as their cost of funds, despite their pretense of setting their prime on the basis of a formula which marks up the rate over the cost of funds. The high prime was maintained in an attempt to create some pricing discipline in the banking industry. But according to a Federal Reserve study, the large New York banks could not maintain the cartel: in the first six months of 1980, more than two-thirds of all loans were made at rates well below the prime. ${ }^{91}$ The political process will probably engage in contributory manslaughter. Representative Henry Reuss, chairman of the House Banking Committee, recently attacked "prime-rate falsies fashioned by the major banks that would shame the nation's brassiere industry," claiming 


\section{OMESTICSTAGFLATION}

that banks charged small customers the prime "falsie" and above, while giving cut-rate deals to the large corporations. ${ }^{92}$

Competition in the United States has been accompanied by even fiercer competition abroad. The share of the top 50 American banks in the banking business of the world's top 10o banks has declined steadily since 1969. In 1969, the largest 50 American banks made 40 percent of the top 100 world banks' loans; in 1979, their share was cut to 21 percent. ${ }^{93}$ These data refer to both domestic and international banking business. The data on international business alone (loans made and deposits accepted outside the home country) mirror these overall figures. In 1974, the American banks accounted for 45.7 percent of the world's international banking loans and other claims; in 1979, they accounted for 30.3 percent. The largest drop occurred between 1977 and 1978 , as the dollar was rapidly depreciating, when the United States' share declined by over 16 percent. ${ }^{94}$

The decline in the share of bank lending has been most dramatic among the OPEC countries. ${ }^{95}$ Between December 1977 and June 1979, the share dropped by almost a third to 35 percent. The other largest drop occurred in the loans to non-oil-exporting Third World countries. Here the share dropped from 54 percent in December 1976 to 48 percent in December 1977 and to 38 percent in June 1979. Among the Third World countries, the decline has been particularly steep in Latin America. The only non-oil-exporting countries where American banks increased their share of lending were Chile, Colombia, South Korea, the Philippines, Thailand, and Egypt.

The drop in the share of bank lending to oil-exporting countries has been accompanied by a decline in the share of OPEC bank deposits that have accrued to American banks from 42 percent in 1975 to 36 percent in 1978. ${ }^{96}$ The share deposited in overseas branches of American banks has stayed constant, however, which means that the decline has occurred in deposits held in American banks in the United States. There is some evidence that this trend has substantially accelerated since 1978-some have attributed the decline over that period to the freeze of Iranian assets in November 1979. ${ }^{97}$ These figures suggest that the fear that rapid American inflation would lead OPEC countries to diversify out of dollars might well have some basis in fact. Along with the decline in the share of international lending has come a decline in the share of profits the largest American banks derive from their international business. Whereas from 1970 to 1975 the share of profits accruing to the top ten banks involved in international lending was over 45 percent, it had dropped in 1979 to 37 percent. The growth rate of international earnings declined substantially for every bank among the top ten between 1970 and 1975 and 1975 and 1979. ${ }^{98}$

Increased competition partly accounts for the decline of American banks in international lending. Another factor is that international lending has become riskier. By December 1977, the nine largest American banks had lent out to non-oil-exporting Third World countries over 180 percent 


\title{
THE HIDDEN ELECTION
}

of their capital accounts, which are supposed to serve as a buffer in case of default. ${ }^{99}$ The exposure of the large banks had not declined by June 1979, and has probably increased since then. While the risk associated with commercial bank lending to the Third World has remained high, and in the past year has undoubtedly increased, the profitability of lending to oil-importing countries has declined due to increased competition among multinational banks. The percentage by which loans are marked up over the cost of funds was lower at the end of 1979 than it had been before the first oil price hike in 1973, and only half as high as it had been in 1976.100

Increased competition always concerns corporations, and bankers are no exception. Through the years, bankers have tried to find means to reduce competition among themselves. One major way is to try to coordinate pricing policies. An especially interesting attempt was made at a recent international banking meeting by Wilfried Guth, managing director of Deutsche Bank in Frankfurt.

Guth decried the long, sad story of reduced profitability of international lending:

\begin{abstract}
After the Herstatt crisis, [interest] spreads recovered from an intolerably low level. ... Since then we have experienced an almost uninterrupted decline in margins. ... In situations like this we tend to give the blame to the market. But who is the market? Must we say in paraphrasing Sartre: The Market-that is the others (the other banks?) . . . So why did we let the market dictate what we didn't want? ${ }^{101}$
\end{abstract}

The culprits are not hard to discover. "We all know what the main reasons for this are ... our very keen competition. Undoubtedly these trends have been reinforced by the continuous appearance of ambitious newcomers to the market who are eager to acquire leading positions by offering favorable rates." What is the solution to this unhappy state of affairs? Guth suggests that perhaps the bankers" profit calculations have been faulty: "I can merely guess that by applying all defensible cost saving calculations, one would arrive at a minimum average acceptable margin somewhere around I\%. . . ." Praising the power of science, Guth concludes: "Thus simple mathematics again demonstrate the need for a wider range of margins than ones we have manoeuvred ourselves into." Almost as an afterthought, he adds: "I am, of course, aware that our distinguished friends on the borrowing side will not appreciate this statement. ..." But, as Guth noted at the outset, especially when there are hungry newcomers, banks have extreme difficulty cooperating. Signals from central bankers might help. Volcker has suggested that "Higher spreads and shorter maturities may well be necessary to induce lenders to assume the greater risks in lending." ${ }^{102}$ Wallich has been even more vociferous. "I've said a million times, spreads are totally inadequate."103

Central bankers are, of course, concerned with more than commercial bank profits. Their concern is with the stability of the international finan- 
DOMESTICSTAG F LATION

cial system. But a coalition of interests forms around both, especially when the foreign newcomers are to blame. However, just as price fixing could not stabilize the economy during the Great Depression, merely fixing spreads will not solve the recycling problem. ${ }^{104}$ Larger problems require larger restructuring, an issue to which we will return.

As domestic and international competition step up, the large banks turn to the Fed and the government for relief. The passage of the Depository Deregulation and Monetary Control Act is only the first victory by the large banks in their attempt to centralize, or as Business Week puts it, "rationalize" the banking industry. ${ }^{105}$ The Carter administration conducted a two-year study analyzing the possibility of reducing restrictions on the movement of banks across state lines. Although the study was essentially finished well before November, the administration delayed releasing it until after the election, obviously concerned about its political impact on small bankers and their friends. The study calls for the phasing out of antibranching laws over a number of years. This will enable large banks to buy out smaller commercial banks in other states as well as set up branches in states in which other large banks already have a dominant market position.

The Fed has given provisional approval to the establishment of "free banking zones" in which bank activities financing or gaining deposits from international business will not be subject to reserve requirements and other lending restrictions that apply to domestic banking. It is not at all unlikely, however, that banks engaging in domestic business will be able to get around the legislation. If such activities were not subject to Fed control, however, the Fed's control over the money supply might well be further eroded. The creation of an international free banking zone will make a minuscule ripple of instability, however, compared to the dangers involved in the evolution of international trade and financial competition in the context of the vast redistribution of wealth and power from the Third and Western worlds to OPEC.

If such dangers are to be avoided, it is necessary (but certainly not sufficient) to resolve two related issues among the advanced capitalist countries. The first is the instability in the international financial markets which is endangering international finance and trade while inhibiting domestic economic growth. The second issue is the vast debt owed by the Third World and Eastern European countries to Western banks. These debts require that the industrialized countries continue to grow and import or find some other means to ensure that these banks are repaid. As it turns out, a joint solution to these problems is being fashioned by the United States government and the Federal Reserve. But the attempts by the Fed and the Treasury to maintain the international financial role of the United States, and the desire of Europe and Japan to expand theirs, will make any coordinated action to salvage the international financial system difficult. In many ways, the problems plaguing the system are further manifestations of those plaguing Bretton Woods: the American share in world production 


\section{THE HID DEN ELECTION}

has dropped from 40 percent in 1950 to only 20 percent in 1979, but the dollar is still used as the world's major reserve currency. ${ }^{106}$ In 1979, at least 65 percent of the world's official foreign exchange reserves were held in dollars. Thus there is a major discrepancy between the greatly reduced economic importance of the United States and the relatively large role of the dollar. The issue that arose in the 1960s arises now in even starker form: the inability of the international financial community to move to a new system might well result in major financial instability or in the necessity of a tight United States monetary policy. Such a policy could impose heavy burdens on the American economy and world economic growth. ${ }^{107}$

For the Fed, the immediate implications of this failure now, as in the 1960 s, is that a tight monetary policy is required to protect the value of the dollar. But as before, the willingness to negotiate a reduction in that role might help to stabilize the system and free up domestic monetary policy. A substitution account is again being considered to facilitate that process. A substitution account would allow central banks to deposit excess dollars acquired from years of U.S. balance of payments deficits, rather than selling them on the exchange markets. The substitution account issue was raised in 1978 by Johannes Witteveen, managing director of the IMF. At the IMF's annual meeting in Belgrade in 1979, before the October "revolution," finance ministers and central bankers were able to agree for the first time to propose an account based in the IMF at the upcoming IMF meetings in April 1980. When April arrived, the United States, Germany, and Japan suddenly withdrew their support, and the plan was shelved.

One basic stumbling block in the negotiations concerned the allocation of the costs of the account. If European, Japanese, and OPEC central banks were to be convinced to exchange dollars for some other asset, then the return and risk they received on that asset had to be at least as desirable to them as what they would have been able to achieve on their own. The negotiators had to determine who would bear the interest costs and who would guarantee the value of the assets exchanged for dollars.

The negotiators had also to determine the benefits that would accrue to them and their constituencies from establishing the account. Negotiators from the Treasury Department wanted to stabilize the international currency markets and protect the value of the dollar without at the same time allowing any other particular country or group of countries to achieve a major reserve currency role. As Bergsten, Carter's assistant secretary of the Treasury for International Affairs, recently put it:

My own view is that a world monetary system based on several reasonably important national currencies might be subject to substantial risks and uncertainties. . . . Lest there be misunderstanding, let me make clear that I am not advocating an effort to preserve excessive preeminence for the dollar . . . I am suggesting . . . that we should seek consciously to promote the use of the Special Drawing Right (SDR, the IMF created money) as an alternative to the use of national reserve currencies. ${ }^{108}$ 
DOMESTIC STAG F LATION

When the dollar was stabilized by other means and events, however, the attraction of the fund for the U.S. would quickly fade.

Germany and Japan, on the other hand, had an interest in the account as long as they had an excess of dollars, and as long as they did not want to create another monetary system that would exclude American participation. By April, however, both conditions had been eroded. In December 1978, the European Economic Community agreed to establish the European Monetary System, which came into force in March 1979. In principle, if not in fact, the EMS represented an alternative to the transformation of a world monetary system under the auspices of the IMF. The creation of the EMS directly reduced European support for the substitution account. The creation of the European Currency Unit (ECU) in conjunction with the EMS involved a substitution account of sorts. Members of the EMS deposited 20 percent of their gold and dollar reserves with the EMS in return for ECU. Thus, the Europeans reduced their holdings of potentially unwanted dollars without creating exchange rate instability. Although this might have helped to stabilize the dollar in the short run, in the longer run it represents a European solution over which the United States exercises little control. Finally, as a result of the oil price increases in 1979, European countries began running balance of payments deficits and needed dollars to pay for oil, further reducing their desires for a substitution account.

For its part, the United States negotiators refused in April 1980 to ask Congress to support guarantees for the value of the account that prospective central bank depositors demanded. ${ }^{109}$ It seems safe to say that in an election year, Congress would have been reluctant to guarantee billions of dollars of reserves, especially when much of them were owned by OPEC countries. The United States instead decided to push the IMF to use its member-donated gold stock to provide the backing. The non-oil-exporting Third World countries were particularly opposed to this, however. They correctly see the IMF's gold as partly belonging to them, and even in the best of circumstances many were suspicious that the creation of the fund would limit their choice of reserve holdings in order to allow the United States to continue running balance of payments deficits. ${ }^{110}$

In any case, at least a short-term solution had already been found for the dollar problem that did not depend on the agreement of the Congress or the Third World: Paul Volcker and the Fed had raised interest rates enough to stabilize the dollar. Japan's and Germany's deficits also helped stabilize the dollar, at least in the short run. In the face of the renewed strength of the dollar, financial interests within the United States and the U.S. government were no longer certain that the risks associated with the formal establishment of an internationally controlled account were worth the benefits. If the Fed could independently guarantee the value of dollar reserves without giving up the perceived unilateral benefits associated with the maintenance of the dollar as a reserve currency, there was no point in supporting the account. The cost, of course, would not be legis- 


\section{THE HID DEN ELECTION}

lated by Congress, but would be borne nonetheless by manufacturing profits and the unemployed.

Another reason that the United States withdrew its support of the substitution account is that, apart from Volcker and the Federal Reserve helping to guarantee the value of the dollar, the IMF is indirectly establishing recycling facilities which, in a sense, use the IMF's gold to back an informal substitution facility. The IMF is planning to issue bonds denominated in IMF's unit of account-the SDR-and will use the proceeds to lend to countries having balance of payments problems. That will reduce the amount of dollars in the system relative to the amount of wealth, thereby reducing the risk to dollar holders of a dollar sell off. It will also, of course, reduce the risk to commercial banks, who will have the IMF bear some of the risk of lending to the Third World. Thus, bypassing Congress, the Fed will implicitly guarantee the value of the dollar. Through the recycling facility, the IMF will implicitly use the IMF's gold to guarantee the dollar wealth of the countries that lend to it-presumably OPEC countries-without an explicit agreement from the Third World countries to allow gold to be used for a substitution account.

Congress cannot be bypassed entirely in the international debt underwriting game. Both the IMF and the World Bank are asking member countries for increased contributions. Virtually all the major governmental-financial personnel have urged Congress to supply the funds. A. W. Clausen, former president of the Bank of America, named by President Carter to succeed Robert McNamara as president of the World Bank, was asked in a recent interview how he would convince a conservative Congress to come up with the money. Clausen replied: "I will say to them, and I know many of them, that I am a banker and that in my professional judgment we have no choice but to support this approach. The Marshall Plan worked, ... . and if we don't produce this expanded level of support - comes the revolution. It's as simple as that."111

Extended financing will not be the only method the IMF and World Bank use to ensure that Western banks are repaid and the revolution is avoided. "Adjustment" and "surveillance" are the key terms here. Adjustment of deficits means that the Third World countries will have to reduce domestic consumption in order to export enough products to pay back their debt. Surveillance is the mechanism used to try to ensure that the standard of living within these countries will actually be reduced. As Paul Volcker puts it: "I believe it is especially important under the circumstances for the IMF to play a strong role. The role of the fund is important not only because that institution has sizeable financial resources but mainly because through the good offices of the IMF there is a better chance to achieve the right mix between adjustment and financing." But Volcker insists:

If we urge them to make real adjustments rather than borrowing excessively in the years ahead, they, in turn, will expect us to keep our markets 


\section{O M ESTIC S T A G F L A I O N}

open to their goods. ... If the industrial countries all try hard to improve their trade balances . . . the only outlet would be even larger deficits for the developing countries. . . The traditional notion is that a successful industrial country ought to have a current account surplus. I am not against surpluses, but ... [w] have to avoid the view that only surpluses are acceptable because some countries will have to be in deficit. . . . [I]t is clear that we cannot make long-run progress collectively if we are forced to repeat the $1977-78$ cycle of large U.S. current account deficits and a quick reversion to surpluses in other major OECD countries. ${ }^{112}$

In other words, the Europeans must open their doors to Third World imports.

Volcker spoke these words in March 1980, as he was driving American interest rates up to 20 percent, forcing the Germans to raise theirs. A few months later, C. Fred Bergsten was hailing before an international group the new turnaround in balance of payments surpluses and deficits: "Our export volume has been rising twice as fast as world trade for two and a half years. On the other side of the equation, Japan and Germany have moved into substantial deficit in 1979 and 1980 . . . [which is a] major achievement of the international adjustment process." 113 As Bergsten suggests, U.S. attempts to maintain its international role in the face of its reduced power have been successful, but the international turmoil created in the process might show the victory to have been a Pyrrhic one.

\section{O N C L US I O N}

The need for a basic restructuring in the domestic and international economy is accompanied and made more difficult by a similar need in the realm of mainstream economic doctrine. Conventional economic thought has offered no solution to the basic problem facing the current international system - namely, the need to maintain economic growth, but the inability to do so.

While the two main schools of received economic wisdom differ in important respects, their common terrain is their most important and vulnerable characteristic. The critical promise of the Keynesian revolution is that proper government policy can maintain full employment and economic growth, thereby protecting the capitalist order from both the Left and the Right. Monetarism contends that if government and the Federal Reserve would simply end misguided Keynesian policies, full employment and growth would be achieved by the private market on its own. On the desirability of government intervention, monetarists and Keynesians vigorously disagree. On the ability of capitalism to sustain full employment, however, they are one.

While both Keynesianism and monetarism promise sustained eco- 
THE HID DEN ELECTION

nomic expansion, the new role played by monetarism in recent years belies their ability to honor the pledge. In these inflationary times, monetarism has become the theory of discipline. For many years following the Great Depression, it was widely held that monetary policy was impotent-only fiscal policy mattered. Later, the neo-Keynesian synthesis, hailed by Richard Nixon himself, recognized that money mattered indeed. Though the revival of monetarism in academic circles owes much to Milton Friedman, its success is primarily a recognition that the Federal Reserve could and would use tight money to thwart economic expansion when it found it necessary to stop inflation.

Yet as Margaret Thatcher tries her experiment of reducing the money supply in England, generating the highest level of unemployment since the Depression, monetarism is even losing its appeal as a disciplinary tool. In advanced capitalist economies, contractionary monetary policy primarily reduces output and profits, not inflation, as the monetarists had suggested. And the Keynesians, for their part, have still not figured out how to maintain economic expansion in an internationally integrated financial system based on a declining currency in the face of working-class power. Out of this theoretical wasteland emerged Arthur Laffer's supply-side economics, which offered some ray of hope for noninflationary expansion. But it is pure mystification, and is increasingly coming to be recognized as such.

In this vacuum, it becomes all that much easier for those in power to try to fashion a cure that attempts to do what they know how to do best, armed with only faith that it will cure the ills of the system. Corporate supply-side economics is the strategy to which Reagan will turn. Corporate tax cuts and attempts to cut social spending rather than personal tax giveaways to the rich are the wave of the future. But for the strategy to have some chance of curing the stagflation impasse, a number of conditions must be satisfied.

On the domestic side, success will depend on the ability of the administration to force consumption, social service, and real income losses on the majority of the American people without resorting to inflation.

In the international sphere, success depends on using the offices of the IMF, and perhaps more blatant methods, to convince Europe and Japan to open their markets to the Third World, get debt-ridden Third World countries to reduce their consumption so they can repay their debt, and force OPEC to maintain oil production at a reasonable price. But with the reduced power of the U.S. government abroad and its impaired legitimacy at home, it is unlikely that it can muster the political power necessary to impose these burdens, short of that which comes out of the barrel of a gun.

Short of that solution or of some miraculous mustering of political power at home and abroad, Paul Volcker and the Federal Reserve will have to take charge again to stem the inflationary "excesses" of government. But Volckerism, like Thatcherism, can only inflict harm on the domestic econ- 
D O MESTIC S T A G F L A T I O N

omy; and because the United States is still so important internationally, Volckerism would be far more dangerous.

\section{NOTES}

1. See, for example, David G. Golden and James M. Poterba, "The Price of Popularity: The Political Business Cycle Reexamined," American Journal of Political Science, 24 (November 1980), 696-714; Edward R. Tufte, Political Control of the Economy (Princeton, N.J.: Princeton University Press, 1978); and the reference cited there.

2. Golden and Poterba, among others, cast doubt on the view that presidents have manipulated the economy. Tufte provides support for the theory. All data are from the Economic Report of the President 1981, unless otherwise indicated.

3. The data in this paragraph and the next are from Stephen V. O. Clarke, "Perspective on the United States External Position since World War II," Federal Reserve Bank of New York Quarterly Review, 5 (summer 1980), 22; and William H. Branson, "Trends in U.S. International Trade and Investment since World War II," NBER Working Paper No. 469 (1980), pp. 22-23.

4. The same sort of argument is made in the interesting article by Leonard Rapping, "The Domestic and International Aspects of Structural Inflation," in James H. Gapinski and Charles E. Rockwood, eds., Essays in Post-Keynesian Inflation (Cambridge, Mass.: Ballinger, 1979). See Fred Bloch, The Origins of International Economic Disorder (Berkeley: University of California Press, 1977) for an extremely useful analysis of Bretton Woods and international monetary politics generally. I have drawn heavily on both of these.

5. Raford Boddy and James Crotty, "Class Conflict and Macro-Policy: The Political Business Cycle," Review of Radical Political Economy, 7 (spring 1975), 3. See this article for the best discussion of this conflict. See Thomas E. Weisskopf, "Marxian Crisis Theory and the Rate of Profit in the Post-War U. S. Economy," Cambridge Journal of Economics, 3 (1979), 341-378, for an excellent empirical investigation of the profit squeeze in the postwar United States.

6. R. E. Rowthorn, "Late Capitalism," A Review of Ernest Mandel's Late Capitalism, New Left Review, July-August 1976, and R. E. Rowthorn, "Conflict, Inflation and Money," Cambridge Journal of Economics, I (1977), 215-239; and Samuel Bowles and Herbert Gintis, "The Crisis of Liberal Democratic Capitalism," mimeo, analyze monetary policy and inflation in a framework similar to the one used in this paper. Sam Rosenberg and Thomas E. Weisskopf, "A Conflict Theory Approach to Inflation in the Postwar U.S. Economy," American Economic Review (May 1981) also use a similar model, except theirs assumes that the money supply will accommodate all inflation generated by conflicts over income shares. The argument here is that, while that might be true in the long run as international markets and innovations supply the money that is required to finance transactions, in the medium run, central banks have enough control over the money supply to affect the inflationary process. As a result, a theory of monetary policy is required to explain when inflation will be allowed and when the central bank will generate unemployment to stop it. James R. Crotty and Leonard A. Rapping, "The 1975 Report of the President's Council of Economic Advisers: A Radical Critique," American Economic Review, December 1975, pp. 791-811, and Rapping, "The Domestic and International Aspects of Structural Inflation," 


\section{THE HIDDEN ELECTION}

also take into account the domestic and international financial imperatives on monetary and fiscal policy.

7. See the studies referred to in notes 41 and 42 below.

8. Clarke, op. cit., p. 23.

9. James Tobin, National Economic Policy (New Haven, Conn.: Yale University Press, 1966), p. 124.

10. C. Fred Bergsten, The Dilemmas of the Dollar (New York: New York University Press, published for The Council on Foreign Relations, 1975), pp. 111-112.

11. Branson, op. cit., pp. 77-80.

12. Clarke, op. cit., p. 27.

13. Bergsten, op. cit., p. 81.

14. James Tobin, The New Economics One Decade Older (Princeton, N.J.: Princeton University Press, 1972), p. 14.

15. Quoted in E. Ray Canterbery, Economics on a New Frontier (Belmont, Calif.: Wadsworth, 1968), pp. 155-160. This book is the source of much useful information on economic policy in the Kennedy-Johnson years.

16. Clarke, op. cit., p. 32.

17. See "The Proposed Substitution Account in the IMF," Midland Bank Review, winter 1979, pp. 21-24.

18. Tobin, National Economic Policy, op. cit.

19. See Bergsten, op. cit.

20. Clarke, op. cit., p. 23.

21. Ibid., p. 27.

22. See Bergsten, op. cit., and Crotty and Rapping, op. cit., pp. 791-811.

23. Bergsten, op. cit., p. 31 In.

24. Raymond Lombra, James B. Heredeen, and Raymond G. Torto, Money and the Financial System. (New York: McGraw-Hill, 1980), pp. 396-397.

25. John Kenneth Galbraith, Money: Whence It Came, Where It Went (Boston: Houghton Mifflin, 1975), p. 140. Much of the analysis in this section draws heavily on Gabriel Kolko, The Triumph of Conservatism (New York: Free Press, 1963).

26. Quoted in Kolko, op. cit., p. 251.

27. Ibid., p. 254.

28. See Thomas Ferguson, The Fall of the House of Morgan: Critical Realignments and Industrial Sectors (New York: Oxford University Press, in press).

29. Milton Friedman, "Should There Be an Independent Monetary Authority." in Leland B. Yeager (ed.), In Search of a Monetary Constitution (Cambridge, Mass.: Harvard University Press, 1962), pp. 236-238.

30. In the short run, a greater value of transactions can be financed with the existing money stock.

31. See Maurice D. Levi, "Money and Corporate Earnings," Journal of Money, Credit and Banking, February 1980, pp. 84-93. Levi studied the effects of the money supply on the before-tax earnings of nonfinancial corporations in the 19641975 period. There are several ways in which money supply changes can affect corporate earnings. One is by reducing the real value of the corporation's debt. A second is by reducing the real value of workers' wages. Levi found that increases in the money supply increase real, before-tax earnings briefly. Accelerations in the money supply increase corporate earnings for a longer period of time. He hypothesized that this resulted from lags in the adjustment of wages to prices, citing evidence that there are equal numbers of net debtors and creditors among nonfinancial corporations so that the debt relationship ought to cancel out in the aggregate. After-tax profits are of ultimate interest, however. It seems that apart from the wage process, the major tax effects of inflation are of two kinds: one, historical costing of capital goods increases taxes since it costs more to replace goods than it cost 


\section{DOMEST I C T A G F L A T ION}

to buy them; the other is tax deductibility of interest costs on debt which go up as interest rates increase during inflation. In the aggregate, they seem to balance out. See Franco Modigliani and Richard A. Cohn, "Inflation, Rational Valuation and the Market," Financial Analysts Journal, March-April 1979, pp. 24-44; and James Tobin, "Stabilization Policy Ten Years After," Brookings Papers on Economic Activity, 1 (1980), 19-71.

32. See Crotty and Rapping, op. cit., pp. 791-811. Inflation was still of some help to them. See Levi, op. cit., pp. 84-93. Levi ran his tests after flexible exchange rates had been operating for only a few years, so he could not directly test the argument made here that manufacturing corporations are helped more by inflation under a flexible exchange rate system than under a fixed rate system.

33. See Tobin, "Stabilization Policy," op. cit., pp. 19-71; and Rudiger Dornbusch, "Exchange Rate Economics: Where Do We Stand?" Brookings Papers on Economic Activity I (1980): 143-185.

34. There is a distinction between real and nominal exchange rates, interest rates, and money supplies. Monetarists tend to assume that the Federal Reserve cannot affect the real components in the long run. There is ample evidence, however, that the Fed can affect these for significant periods of time, at least in the United States. See Dornbusch, op. cit., pp. 143-185, and Tobin, "Stabilization Policy," op. cit., pp. 19-71.

35. Clarke, op. cit., p. 32; and International Monetary Fund, Annual Report 1980, p. 26.

36. Anthony M. Solomon, "United States and the World Economy," The Federal Reserve Bank of New York Quarterly Review, 5, 2 (summer 1980), 5.

37. See Jeffrey Sachs, "Wages, Profits and Macroeconomic Adjustment: A Comparative Study," Brookings Papers on Economic Activity, 2 (1979), 269-332.

38. Increased labor share also reduces profits and might reduce investment, leading to slower economic growth.

39. See Economic Report of the President 1981, pp. 184-189.

40. See Sachs, op. cit., and Bowles and Gintis, op. cit.

41. See Sachs, op. cit., p. 81.

42. Tobin, "Stabilization Policy," op. cit., p. 67.

43. See Bowles and Gintis, op. cit. Another reason why firms might be reluctant to reduce wages and would rather lay off workers is that they have developed finely crafted wage differentials to legitimate the hierarchical nature of the firm. They might, therefore, be reluctant to upset these differentials by changing wage scales when demand falls off in response to contractionary policy.

44. For seminal discussions of financial instability created by economic expansion, see work by Minsky-for example, Hyman P. Minsky, Keynes (New York: Columbia University Press, 1975) and "The Federal Reserve: Between a Rock and a Hard Place," Challenge, May-June 1980, pp. 30-36.

45. Leonard Rapping, Review of "Reflections of an Economic Policy Maker," Challenge, November-December 1979, p. 9. In the 1950 and 1960s contractionary monetary policy worked in the first instance by causing a contraction in the housing industry. The political power of the savings and loan and construction industries won a number of regulatory concessions which partially insulated the housing industry from tight monetary policy. That, in turn, has placed more of the burden of tight money on other industries in the war against inflation, but that pattern does not seem to always hold. In the recession of 1980 , housing was hit extremely hard, as it had been in the 1960 .

46. See William Sweet, "Third World Debts," Editorial Research Reports, II, 4 (July $25,1980), 544$. 


\section{THE HIDDEN ELECTION}

47. Paul L. Volcker, "The Recycling Problem Revisited," Challenge, July-August 1980, pp. 12, 10.

48. See Thomas Ferguson and Joel Rogers, "Miller of the Fed," The Nation, August 12-25, 1978 .

49. Rapping, review of "Reflections of an Economic Policy Maker," op. cit., pp. 65-66.

50. See Tufte, op. cit., and Alan S. Blinder, Economic Policy and the Great Stagfation (New York: Academic Press, 1979), chap. 8.

51. See William Poole, "Burnsian Monetary Policy: Eight Years of Progress?" Journal of Finance, May 1979.

52. Blinder, op. cit., chap. 8.

53. Jerry L. Jordan, "Discussion: The Political Economy of Arthur Burns," Journal of Finance, May 1979, pp. 496-498.

54. Fortune, December 31, 1978.

55. Economic Report of the President 1981, p. 30.

56. Morgan Guaranty, World Financial Markets, December 1978.

57. See Federal Reserve Bank of St. Louis Review, March issues, for much useful information on the internal dynamics of monetary policymaking.

58. The New York Times, April 20, 1979.

59. Washington Post, April 19, 1979.

6o. Ibid.

61. Tobin, "Stabilization Policy," op. cit., p. 32.

62. The Wall Street Journal, July 26, 1979.

63. World Financial Markets, October 1979.

64. Business Week, October 22, 1979.

65. U.S. News and World Report, October 22, 1979.

66. Business Week, October 22, 1979.

67. Business Week, April 1, 1972.

68. The Wall Street Journal, November 20, 1979.

69. Business Week, October 22, 1979.

70. The Wall Street Journal, December 13, 1979.

71. Suroey of Current Business, October 1980.

72. See Ray C. Fair, "Estimated Effects of the October 1979 Change in Monetary Policy on the 1980 Economy," NBER Working Paper No. 538 (August 1980).

73. The New York Times, February 22, 1980.

74. The New York Times, February 27, 1980.

75. The Wall Street Journal, February 26, 1980.

76. The Wall Street Journal, February 27, 1980.

77. Ibid., February 25, 1980.

78. Ibid., March 6, 1980.

79. See Federal Reserve Bulletin, August 1980, p. 630.

80. Mlb, seasonally adjusted.

81. Information in the next two paragraphs is taken from the Economic Report of the President 1981.

82. Federal Reserve Bulletin, December 1980, p. 951.

83. There is a great deal of disagreement about the degree to which the profitability of nonfinancial U.S. corporations has declined in the 1970 selative to earlier recent periods. A good number of studies suggest that both before-tax and after-tax rates of return are lower in the period following the middle Ig6os (see Martin Feldstein and James Poterba, "State and Local Taxes and the Rate of Profit in the Post-War U.S. Economy," NBER Working Paper 1980, for example). However, other studies suggest that the after-tax return has remained more or less constant. (See, for example, Modigliani and Cohn, op. cit., pp. 24-44.) What is indisputable, however, is the fact that real 


\section{O M ESTIC STA G F L A T IO N}

after-tax corporate profit growth rate has declined from $2.8 \%$ a year for $1959-1969$ to $1.6 \%$ for 1968-1979; more dramatically, however, stock prices, in real terms, have tumbled in the last ten years; they are about half their historic peak level in 1968. For no other ten-year period, including the Great Depression, have stocks performed so poorly. This poor performance has harmed the wealth of stockholders and the ability of corporations to raise funds for investment in the stock market. See William C. Brainard, John B. Shoven, and Laurence Weiss, "The Financial Valuation of the Return to Capital," Brookings Papers on Economic Activity, 2 (1980), 453-511.

84. The major thing to understand about the 2.5 percentage point decline in productivity growth as between the 1948-1965 period and the 1973-1979 period is that there is virtually no agreement as to what accounts for it. Numerous studies come up with widely different answers to the question, and most careful studies suggest that the decline remains essentially a puzzle. The position taken by the Council of Economic Advisers under Carter in view of this intellectual vacuum is that, even if a decline in investment did not cause a decline in productivity growth, an increase in investment can improve productivity. Of course it's important to realize that increases in productivity won't necessarily reduce inflation. Once again it becomes a question of holding the rate of growth of wages below productivity increases if both profits and inflation are to be substantially improved. See Economic Report of the President 1981 and earlier years.

85. Information in the following paragraph is taken from the Congressional Quarterly, April 12, 1980.

86. Federal Reserve Bulletin, June 1980. See the article in this issue for detailed information on the provisions of the bill.

87. Congressional Quarterly, July 7, 1979.

88. Henry S. Terrel and Sydney J. Key, "The Growth of Foreign Banking in the United States: Analytical Survey," in Key Issues in International Banking, The Federal Reserve Bank of Boston, 1977, pp. 56-58.

89. Randall C. Merris, "The Prime Rate," Federal Reserve Bank of Chicago, Business Conditions, April 1975, reprinted in Thomas Havrilesky and John T. Boorman, Current Perspectives in Banking (Arlington Heights, Ill.: AHM Publishing Corporation, 1976), p. 75.

90. Sherman J. Maisel, Managing the Dollar (New York: Norton, 1973), p. 76.

91. Thomas C. O'Donnell, "What Went Up Comes Down-But Slowly," Forbes, June 23, 1980, pp. 33-34.

92. Ibid.

93. Compiled from various issues of Fortune Magazine.

94. Salomon Brothers, Bank Stock Department, "Lending to LDCs: Mounting Problems," April 2, 1980.

97. Euromoney, July 1980

98. Salomon Brothers, "United States Multinational Banking: Current and Prospective Strategies," June 1976; and Salomon Brothers, op. cit.

99. Volcker, op. cit., pp. 3-14.

100. Ibid.

101. "The Problems Raised by the Growth of International Banking Lending," presentation at the International Monetary Conference, American Bankers' Association, New Orleans, June 1-4, 1980.

102. Ibid., p. 13.

103. The Wall Street Journal, July 2, 1980.

104. See Gabriel Kolko, Main Currents in Modern American History (New York: Harper \& Row, 1976), and Gabriel Kolko, "Intelligence and the Myth of Capitalist Rationality in the United States," Science and Society, summer 1980, pp. 130154 . 


\section{THE HID DEN ELECTION}

105. Business Week, March 24, 1980.

106. See Clarke, op. cit., p. 22. If ECU are counted as part of the world's foreign exchange reserves, the share of reserves held in dollars fell from a high of over $86 \%$ in 1976 to $65 \%$ in 1979. If, on the other hand, the ECU substituted for dollars are counted as dollars and those substituted for gold are eliminated from the total foreign exchange holdings, then the dollar share in 1979 is almost $78 \%$, which would still comprise a drop of 9 percentage points. The most dramatic change over the period, however, is the decline of sterling, from the currency with the second largest share in 1973 to the fifth largest, and the dramatic rise in the use of the German mark and the Japanese yen as reserve currencies. The pattern of increased use of the dollar around the time of the first OPEC price increase in 1974 is reflected in official holdings as well. But this second OPEC price rise did not induce a similar rebound. Though an increase in the use of the dollar might appear in later statistics, the creation of the ECU and the active attempts of the Germans, Swiss, and, to some extent, Japanese to make their currencies into reserve currencies will make it less likely that the OPEC increase by itself will resurrect the dollar this time around.

The relative maintenance of the dollar's share in international reserves in the face of a decline in the United States' share of world production might mask substantial changes in the composition of reserve holdings among different countries. In particular, those who worry about the stability of a multiple reserve asset system seem to be primarily concerned with Third World and oil-exporting countries diversifying out of dollars. But data on such diversification are difficult to come by. Detailed data on holdings by particular countries outside the major European countries are not available after 1977, and as suggested earlier, these data are strongly influenced by the high demand for dollar reserves following the first OPEC price rise. However, one can calculate the minimum probable holdings of dollars by assuming that the Group of 10 Countries plus Switzerland hold all their reserves in dollars and then figuring what proportion the rest of the world holds. If this experiment is performed, one discovers that in 1979 the share of dollar holdings in the rest of the world is $60.3 \%$ if the ECU is excluded and $37.6 \%$ if the ECU is included as foreign exchange reserves. This, of course, is a bare minimum. The Group of 10 Countries and Switzerland probably hold around $90 \%$ of their reserves in dollars.

The investment and commercial bankers had warned that the breakdown of the Bretton Woods system and the advent of floating exchange rates would lead multinational corporations and central banks to reduce their holdings of dollars, increase their use of other currencies, and, through the "Siamese twin" effect, would lead to a reduction in the market share of U.S. financial institutions. They also warned that an international financial system based on the use of more than one currency (a multicurrency system) and floating exchange rates would be unstable and costly.

We have seen that the market share of U.S. banks in international finance has indeed fallen. That reduced share has been accompanied by a reduction in the use of the dollar relative to other currencies in both private and official capacities. The dollar's share fell from $78 \%$ of the total banking claims in 1974 to $68 \%$ in 1979 . The drop in the share of international bonds denominated in dollars is even greater, from $63 \%$ of the total in 1974 to $42 \%$ in 1979. The share of dollar-denominated bonds increased somewhat during the heavy financing associated with the first OPEC price increase in 19741976, but dropped off afterward. The same phenomenon occurred in the 


\section{DOMEST IC S T A G F A T IO N}

Eurocurrency Market. But the long-run trend appears to be a decline.

107. See Rapping, "The Domestic and International Aspects of Structural Inflation," op. cit., and Block, op. cit., for a similar argument.

108. C. Fred Bergsten, "International Monetary System in the 1980's," in Bergsten, The World Economy in the 1980's: Selected Papers of C. Fred Bergsten, 1980 (Lexington, Mass.: D. C. Heath and Co., 1981), pp. 23-37.

109. H. Johannes Witteveen, Annual Report of the Group of Thirty (Consultative Group on International Economic and Monetary Affairs, Inc., 1980), p. 3.

110. I. S. Gulati, "New Substitution Account Proposal," Economic and Political Weekly, April 19, 1980, pp. 743-748.

111. Euromoney, December 1980.

112. Volcker, op. cit.

113. Bergsten, "International Monetary System in the 1980's," op. cit. 